\begin{tabular}{cccc} 
Available online at www.sinjas.journals.ekb.eg & \\
\hline SCREENED BY SINAI Journal of Applied Sciences
\end{tabular}

\title{
A STUDY OF THE ECONOMIC EFFICIENCY AND PRODUCTIVITY OF PEACH CROP IN NORTH SINAI GOVERNORATE
}

\author{
Sayed S. Abd El-Aziz ${ }^{1 *}$, S.A. Ibrahim ${ }^{1}$, R.M. Hefny ${ }^{1}$ and M.K. El-Rehan ${ }^{2}$ \\ 1. Dept. Econ. and Rural Dev., Fac. Environ. Agric. Sci., Arish Univ., Egypt. \\ 2. Dept. Econ., Fac. Agric., Ain Shams Univ., Egypt.
}

\begin{tabular}{l} 
ARTICLE INFO \\
\hline Article history: \\
Received: $23 / 07 / 2021$ \\
Revised: $09 / 10 / 2021$ \\
Accepted: $15 / 10 / 2021$ \\
Available online: $15 / 10 / 2021$ \\
\hline Keywords: \\
Peach crop, \\
economic efficiency and \\
productivity, \\
production and cost \\
functions, \\
North Sinai Governorate \\
D \\
Check for \\
updates
\end{tabular}

\begin{abstract}
Peach is considered one of the most important fruit crops in Egypt due to its widespread cultivation, in addition to its importance as an important fruit crop at the local level, where the peach crop comes in second rank in terms of the relative importance of the fruit acreage in North Sinai Governorate. The research aims to analyze the productive and economic efficiency and study the current productive situation in Egypt and North Sinai Governorate, and the study relied on secondary primary data, Results sh0wed that the average total area It reached about 75.8 thousand faddans. The average fruitful area amounted to about 68.5 thousand acres. The average per faddan productivity was about 5 tons/faddan. The average total production amounted to about 333.7 thousand ton. It was also found that the average crop area in Al-Arish and of Rafah districts amounted to about 535.6 and 33.1 thousand faddans, respectively. This is from the average governorate, which is about 54,600 faddans. The average tree productivity was about $26.2 \mathrm{~kg} / \mathrm{year}$, and the average faddan productivity was about 3.147 ton/year. The study recommends the importance of renewal for large and low-productivity trees with the application of chemical fertilization programs.
\end{abstract}

\footnotetext{
الفاكهـة فـي محافظــة شــمال سـيناء وذلــك مسن خــلال استعر اض الأهداف الفر عية التالية:

1-در اسـة الوضـع الإنتاجي الر اهن لمحصول الخوخ في سي مصر ومحافظة شمال سيناء الإنياء

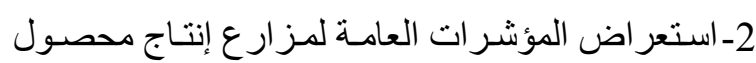
الخوخ داخل عينة الدر استة.

3- التحليل الاقتصادي والقياسي لاهم العناصـر المستخدمة

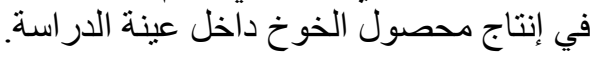

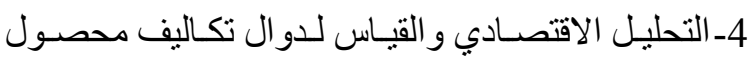

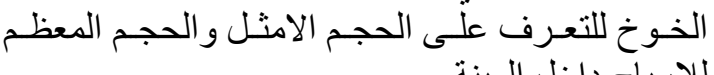
للارباح داخل العينة$$
\text { الطريقة البحثية }
$$

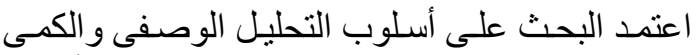

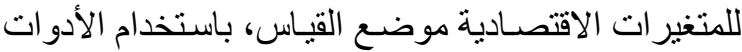

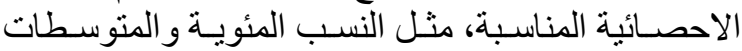$$
\text { يعتبر انخفاض متوسط إنتاجية فدان الخوخ بمحافظة }
$$

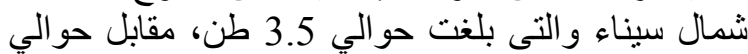$$
8.2 \text { طن في جمهورية مصر العربية، وبنسبة انخفاض }
$$

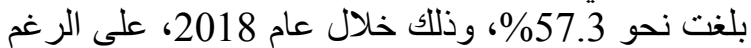
من ان محافظة شمال سيناء تحتل المرنبة الأولي من حيث

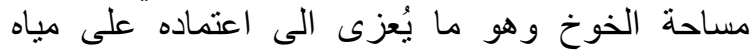

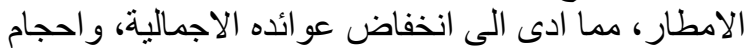

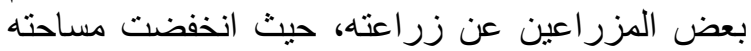

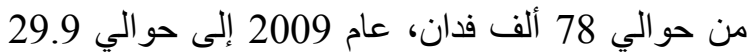
ألف فدان عام 2017، بنسبة انخفاض بلغت عام نحو خلال هذه الفترة. (أبو الروس، عام 2020).

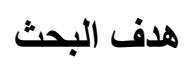

يهرف البحث بصفة عامة الى تحليل الكفاءة الإنتاجيـة و الاقتصادية لمحصول الخوخ، باعتبار هن أهم محاصيل تحنيل

\footnotetext{
* Corresponding author: E-mail address: s01001717442@ gmail.com https://doi.org/10.21608/sinjas.2021.87146.1035

(C) 2021 SINAI Journal of Applied Sciences. Published by Fac. Environ. Agric. Sci., Arish Univ. All rights reserved.
} 
تنتاقص سنوياً بمقدار معنوي إحصائياً بلغ حوالي 1.90

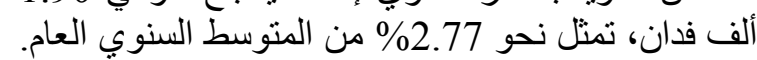
وتشير التقدير ات أن معامل التحديد قد بلغ نحو 0.61.

\section{تطور الإنتاجية الفدانية من محصول الخوخ}

تشير النتائج الواردة بجدول 1 بأن الإنتاجية الفدانية

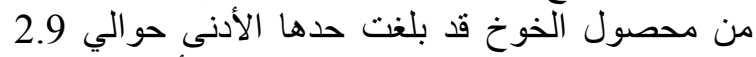

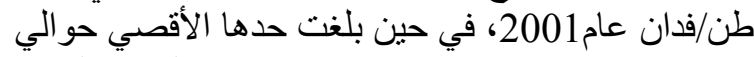

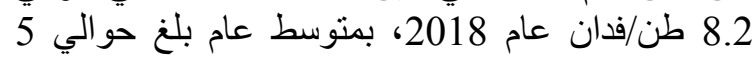

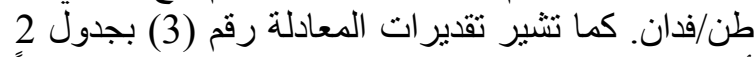

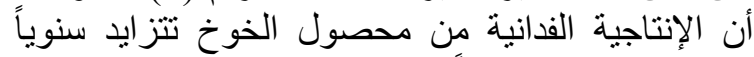

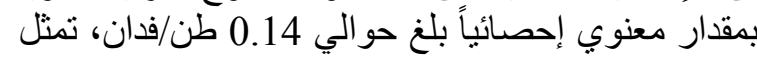

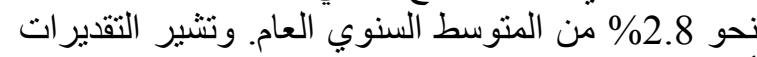
أن معامل التحديد قد بلغ نحو

\section{تطور الإنتاج الكلي من محصول الخوخ}

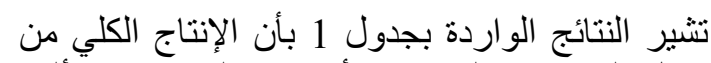

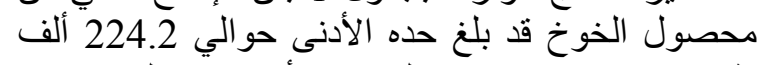
طن عام 2001، في حين بلغ حده الأقصى حلى حوالي 427.6

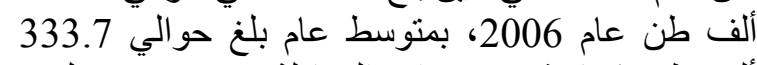

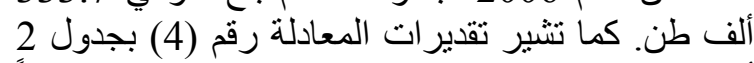

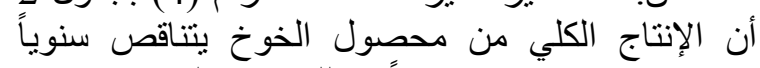

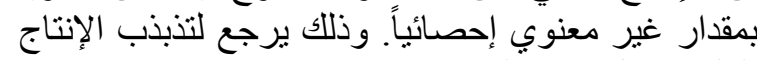

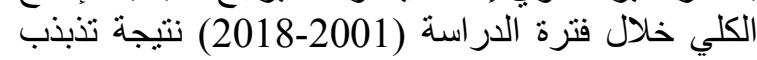

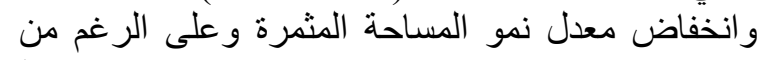

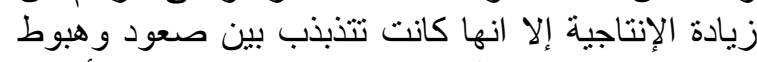
حيث كانت تزيد بمعدل متناقص حتى الإنى 2010 بعدها أخذات في الزيادة

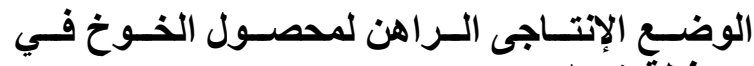

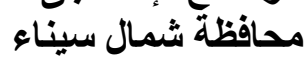

تطور المساحة المزروعة من محصول الخوخ في

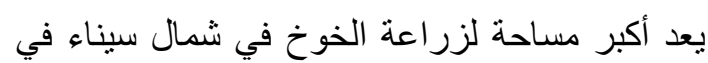

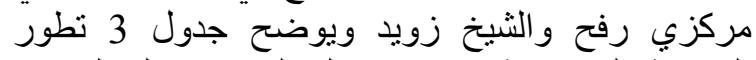

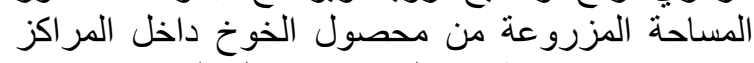
الإدارية في محافظة شمال سيناء خلال الفنترة (20002017) كماً يلي: في الإدارية في

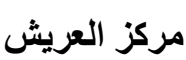

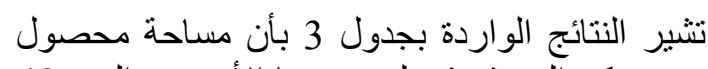

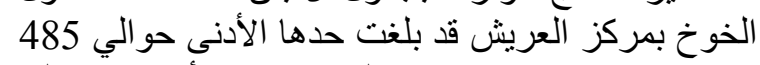

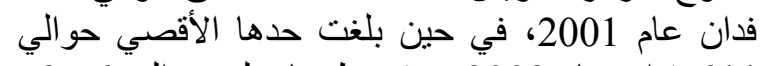

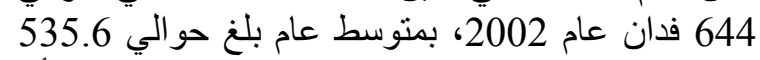

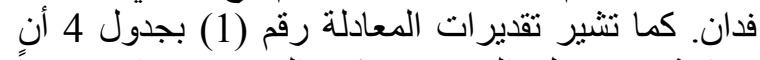

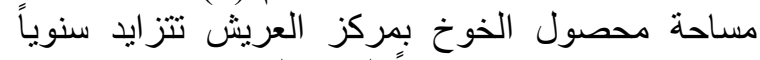

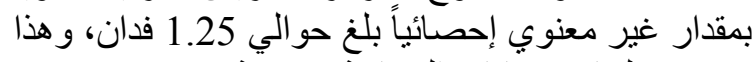
قد يرجع لتقارب بيانات المساحة من سنّة لاخرى.

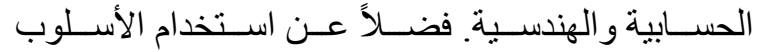

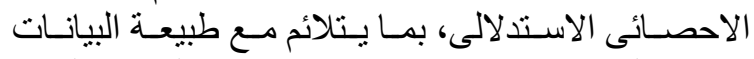

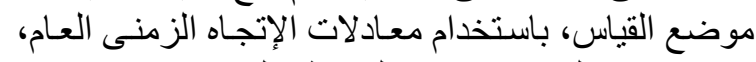

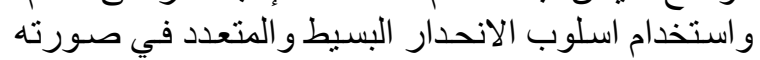

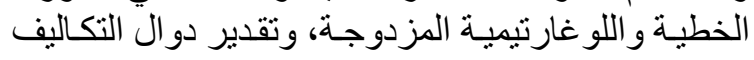
في الصورة التكعبية.

\section{مصادر جمع البيانات}

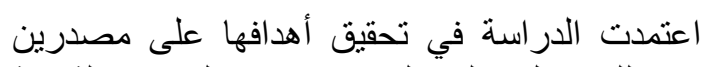

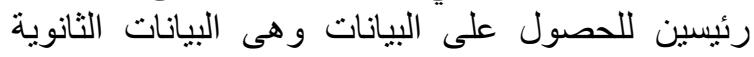

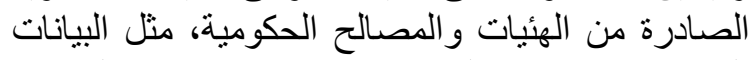

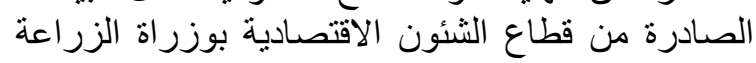

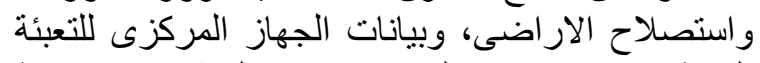

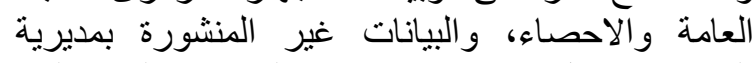

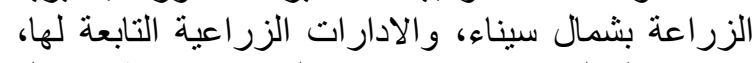

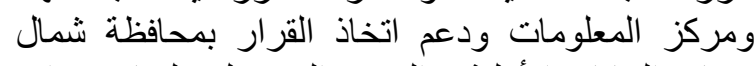

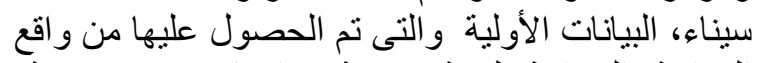

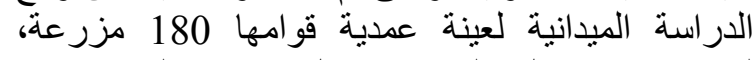

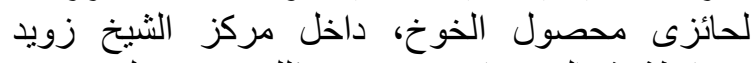

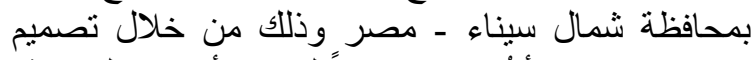

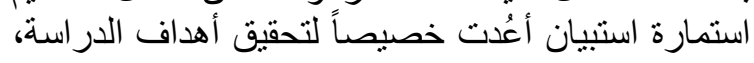

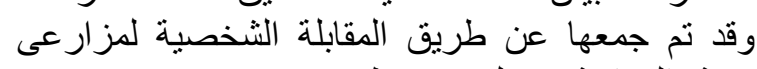
عينة الدراسة خلال منوسط طريق موسمى (2020/2019) بسبب تفاوت الإنتاجية الفدانية خلال هذئل هذين الموسمين كنتيجة لظاهرة المقاومة في محاصيل الفاكية لفاكة.

\section{التتائج ومناقشتها}

\section{الوضع الإنتاجي الراهن لمحصول الخوخ في مصر تطور المساحة الكلية}

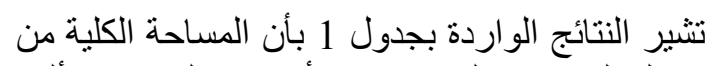

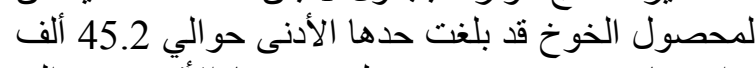

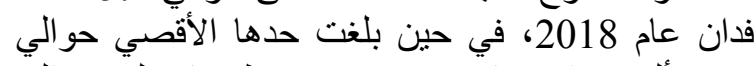

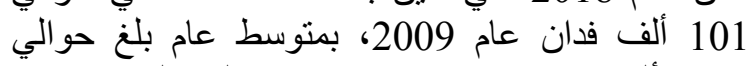

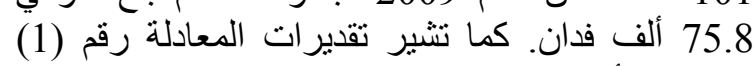

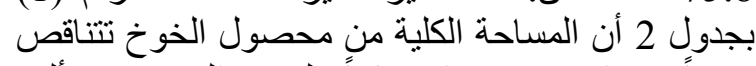

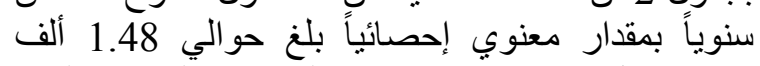

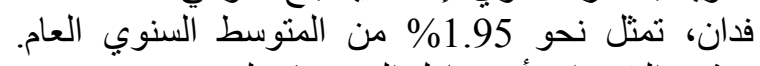

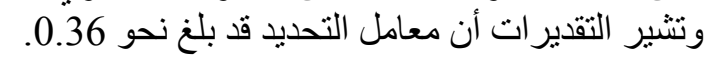

\section{تظور المساحة المثمرة}

تشير النتائج الواردة بجدول 1 بأن المساحة المثمرة من محصول الخوخ قد بلغت حدها الأدنى حو الي 32.7

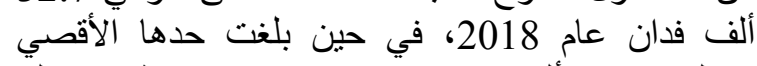

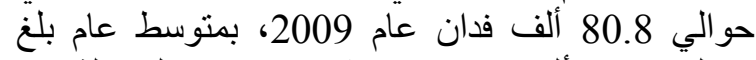
حوالي 68.6 ألف فدان. كما تشير تقدير ات الف المعادلة رقم

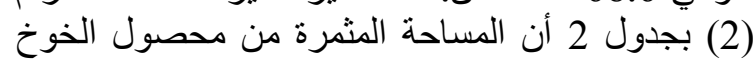


جدول 1. تظور الوضع الراهن لمحصول الخوخ في مصر خلال الفترة (2001-2018)

\begin{tabular}{|c|c|c|c|c|}
\hline الإنتاج الكلى (ألف) & 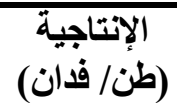 & (ألف فداحة المثمرة & ألمساحة الكلية & السنة \\
\hline 224.18 & 2.92 & 76.77 & 78.49 & 2001 \\
\hline 339.27 & 4.54 & 74.66 & 76.78 & 2002 \\
\hline 302.67 & 4.06 & 74.63 & 78.65 & 2003 \\
\hline 360.94 & 4.77 & 75.59 & 79.20 & 2004 \\
\hline 409.65 & 5.30 & 77.31 & 79.40 & 2005 \\
\hline 427.64 & 5.45 & 78.40 & 82.11 & 2006 \\
\hline 425.27 & 5.41 & 78.67 & 83.70 & 2007 \\
\hline 399.42 & 4.98 & 80.20 & 100.62 & 2008 \\
\hline 363.21 & 4.50 & 80.75 & 100.98 & 2009 \\
\hline 273.26 & 3.48 & 78.61 & 80.61 & 2010 \\
\hline 332.49 & 4.46 & 74.42 & 76.69 & 2011 \\
\hline 285.19 & 4.50 & 63.36 & 67.68 & 2012 \\
\hline 281.12 & 4.74 & 59.37 & 68.38 & 2013 \\
\hline 290.00 & 4.75 & 61.07 & 75.09 & 2014 \\
\hline 269.57 & 5.34 & 50.50 & 65.92 & 2015 \\
\hline 328.39 & 6.00 & 54.72 & 60.88 & 2016 \\
\hline 425.45 & 6.83 & 62.32 & 64.25 & 2017 \\
\hline 269.36 & 8.22 & 32.75 & 45.19 & 2018 \\
\hline 333.73 & 5.01 & 68.56 & 75.81 & المتوسط \\
\hline
\end{tabular}

جدول 2. معادلات الاتجاه الزمني العام لأهم المتفيرات الاقتصادية المرتبطة بمحصول الخوخ في مصر خلال الفترة (2018-2001)

\begin{tabular}{|c|c|c|c|c|c|}
\hline $\mathbf{F}$ & $\mathbf{R}^{2}$ & معدل النمو السنوي \% & المعادلة & المتغير & رقم المعادلة \\
\hline$* * 9.17$ & 0.36 & $(1.95)$ & $\begin{array}{l}\widehat{\mathbf{Y}}_{1}=89.9-1.48 \mathbf{T I} \\
(16.95)^{* *}(-3.08)^{* *}\end{array}$ & (ألف فداحة الكلية) & 1 \\
\hline$* * 24.6$ & 0.61 & $(2.77)$ & $\begin{array}{l}\widehat{\mathbf{Y}}_{2}=86.64-1.90 \mathbf{T I} \\
(20.88)^{* *}(-4.96)^{* *}\end{array}$ & (ألف فداحة المثرة & 2 \\
\hline$* * 11.3$ & 0.41 & 2.79 & $\begin{array}{c}\widehat{\mathbf{Y}}_{3}=3.65+0.14 \mathbf{T I} \\
(7.93)^{* *}(3.37)^{* *}\end{array}$ & الإنتاجية الفدانية فدان) & 3 \\
\hline 0.35 & 0.02 & $(0.53)$ & $\begin{array}{c}\widehat{\mathbf{Y}}_{4}=350.43-1.76 \text { TI } \\
(10.94)^{* *}(-0.59)\end{array}$ & (الإنتاج الكلي & 4 \\
\hline \multicolumn{6}{|c|}{ 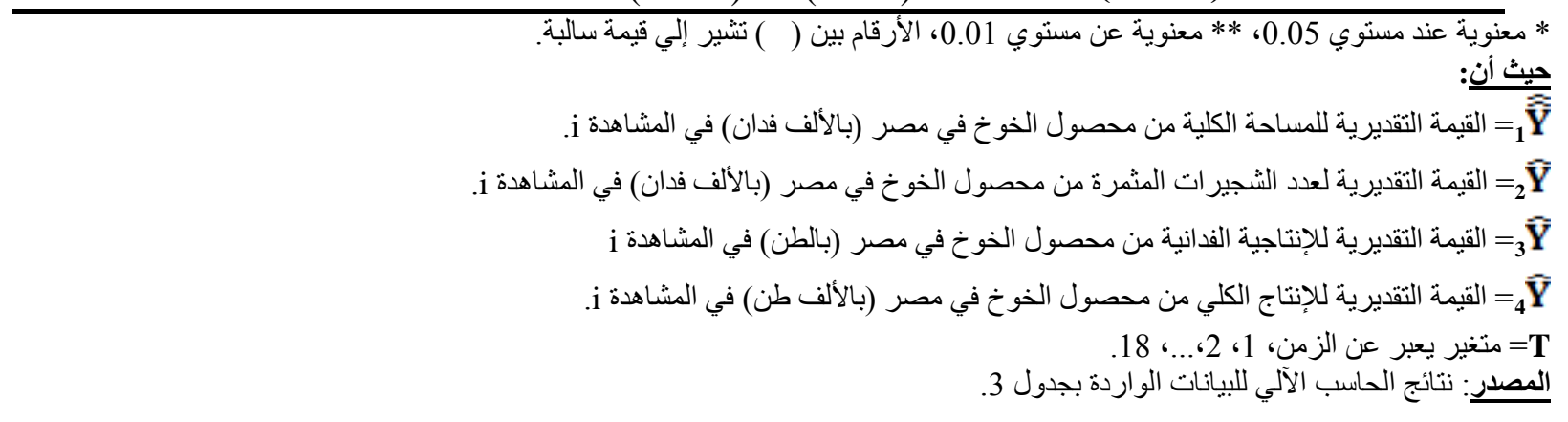 } \\
\hline
\end{tabular}


جلول 3. تطور المساحات المزروعة من محصول الخوخ داخل المراكز الإدارية بمحافظة شمال سيناء خلال الفترة .(2017 -2000)

\begin{tabular}{|c|c|c|c|c|c|c|c|}
\hline الإجمالي & نخل & الحسنة & بئر العبد & الثيخ زويد & رفح & العريش & السنة \\
\hline 61890 & 10 & 410 & 1215 & 23043 & 36700 & 512 & 2000 \\
\hline 61441 & 10 & 171 & 1046 & 22697 & 37032 & 485 & 2001 \\
\hline 59257 & 11 & 64 & 879 & 20519 & 37140 & 644 & 2002 \\
\hline 59048 & 11 & 44 & 897 & 20519 & 37069 & 508 & 2003 \\
\hline 59001 & 11 & 19 & 789 & 20608 & 37083 & 491 & 2004 \\
\hline 59336 & 11 & 39 & 779 & 20889 & 37114 & 504 & 2005 \\
\hline 60570 & 23 & 39 & 825 & 21234 & 37932 & 517 & 2006 \\
\hline 50446 & 10 & 39 & 454 & 21598 & 27833 & 512 & 2007 \\
\hline 77297 & 7 & 49 & 541 & 32919 & 43214 & 567 & 2008 \\
\hline 78000 & 3 & 44 & 477 & 33667 & 43214 & 595 & 2009 \\
\hline 61868 & 2 & 27 & 413 & 24257 & 36612 & 557 & 2010 \\
\hline 57975 & 2 & 27 & 411 & 20700 & 36297 & 538 & 2011 \\
\hline 46108 & 2 & 17 & 12 & 15451 & 30097 & 529 & 2012 \\
\hline 41522 & 0 & 44 & 10 & 15469 & 25487 & 512 & 2013 \\
\hline 40746 & 0 & 45 & 11 & 15426 & 24760 & 504 & 2014 \\
\hline 40790 & 0 & 45 & 10 & 15416 & 24760 & 559 & 2015 \\
\hline 38782 & 0 & 44 & 0 & 14826 & 23355 & 557 & 2016 \\
\hline 29886 & 0 & 43 & 0 & 9014 & 20279 & 550 & 2017 \\
\hline 54664.6 & 6.3 & 67.2 & 487.2 & 20458.4 & 33109.9 & 535.6 & المتوسط \\
\hline
\end{tabular}

جدول 4. معادلات الإتجاه الزمني العام لتطور المساحة المزروعة بمحصول الخوخ في محافظة شمال سيناء خلال الفترة .(2017-2000)

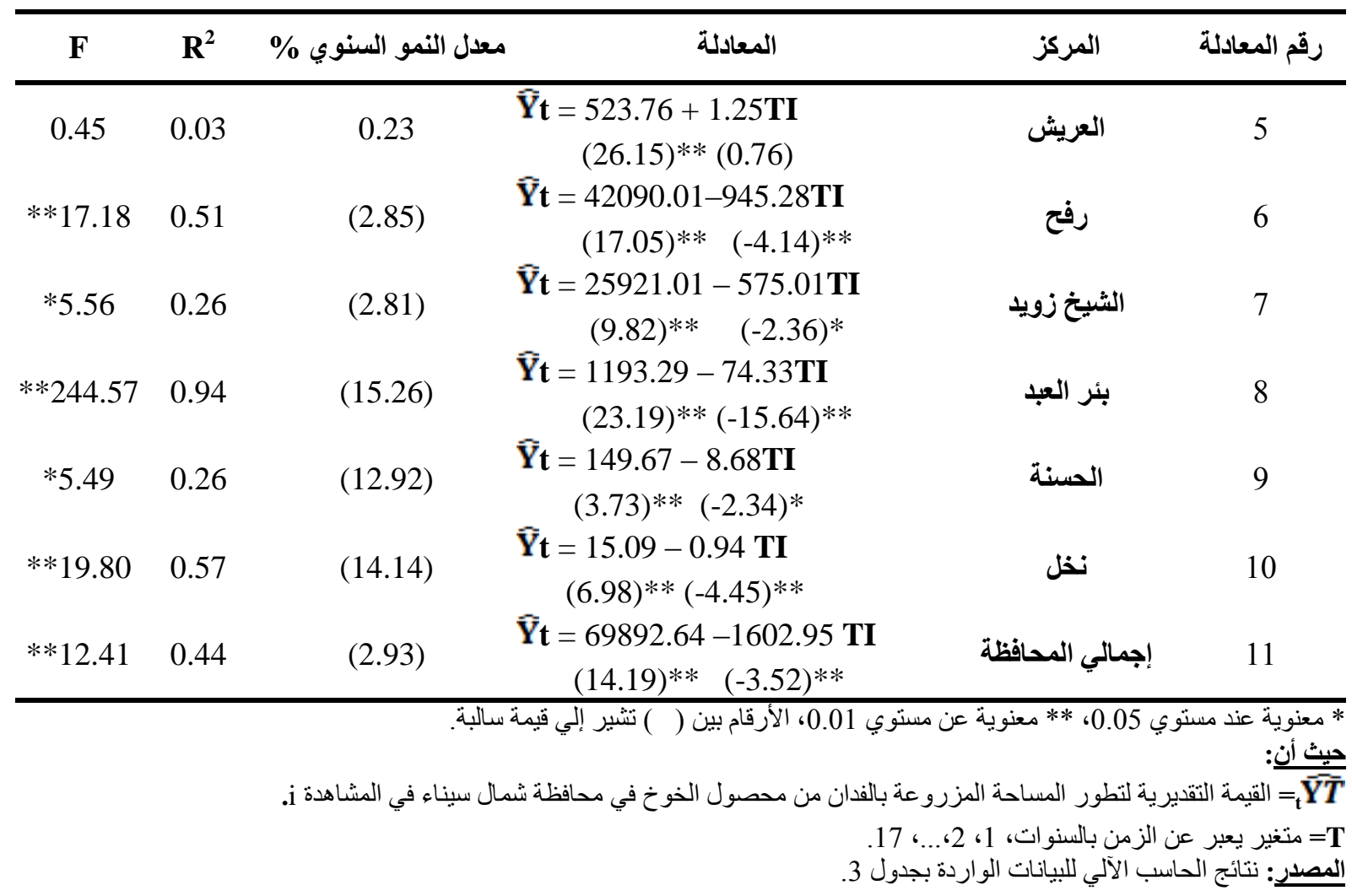




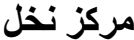

تشير النتائج الواردة بجدول 3 بأن مساحة محصول

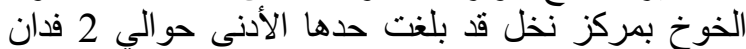

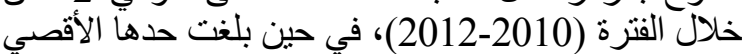

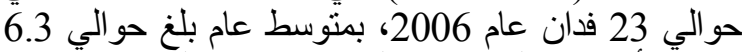
فدان. و وأنعدت المساحات المزروعة من الخوخ من عن عام 2013. وتثثير تنقير ات الدعادلة رقم (10) بجدول 4 أن أن

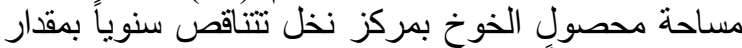

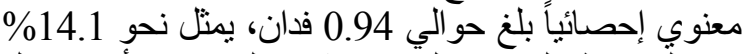
من الكنوسط السنوي العالم. وتثنير التقليرات أن معامل التحديد قد بلغ نحو النتوب.

\section{إجمالي المحافظة}

تثثير النتائج الواردة بجدول 3 بأن مساحة محصول

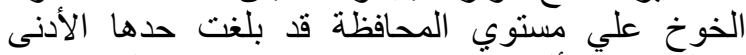

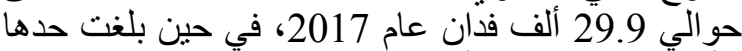
الأقصي حوالي 78 ألف فدان عام 2009، 2009، بمتوسط عام الثما ربلغ حوالي 54.7 ألف فدان. كما تثنير تقديرات المات المعادلة

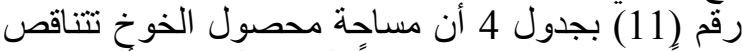

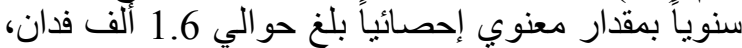
يمثل نحو 2.9\% من المتوسط السنوي العام. وتثنير التقدير ات أن معامل التحديد قد بلغ نحو 0.44.

اختيار عينة الاراسة من محصول الخوخ في محافظة

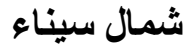

\section{اختيار مركز الاراسة من محصول الخوخ في محافظة

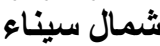

يوضح جدول 5 الأهمية النسبية للمساحة الثثمرة

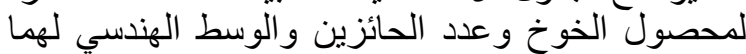

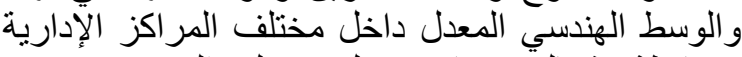

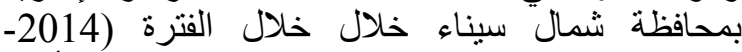
2017)، حيث يتبين ان مركز رفح يحتل المرنبة الأولي من حيث المساحة المثمرة والبالغة حو الي 23289 فل فدان، تمثل نحو 62\% من جملة المساحة المثمرة داخل المحافظة، كما يحتل أيضاً المرتبة الاولي من حيث الئ عدد الحائزين

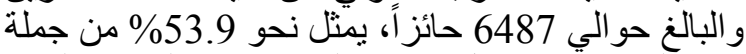
عدد الحائزين. ويحتل مركز الثنيخ زويد المرتبة الثانية

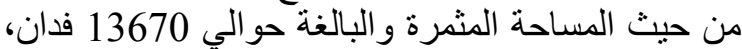
تمثل نحو 36.4\% من جملة المساحة المثمرة داخل

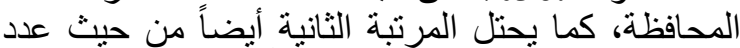

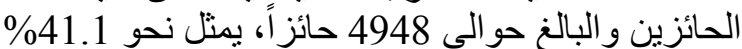
من جملة عدد الحائزين. ويحتل مركز العريش المرتبة الثالثة من حيث المساحة المثمرة و البالغة حو الي 543 فدان، تمثل نحو 1.5\% من جملة المساحة المثمرة داخل المحافظة، كما يحتل أيضاً المرتبة الثالثة من حيث الثيث عدد

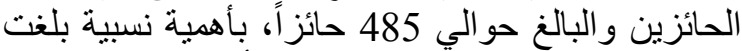
نحو 4\% من جملة عدد الحائزين. ثم يأني مركزي الحسئة وبئر العبد في المرتبتين الاخيرتين من حيث المبن المساحة

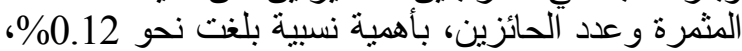
0.01 من جملة المساحة المثمرة داخل المحافظة و البالغة

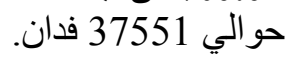

مركز رفح

تثير النتائج الواردة بجدول 3 بأن مساحة محصول الخوخ بمركز رفح قد بلغت حدها الأدنى حوالي 20.3

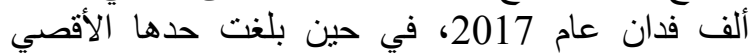

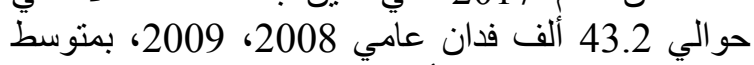

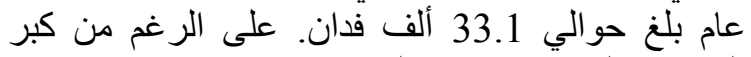

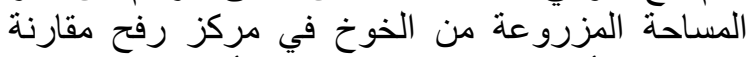
بالمراكز الأخرى في شمال سيناء إلا أنه تثير تقدير تقديرات

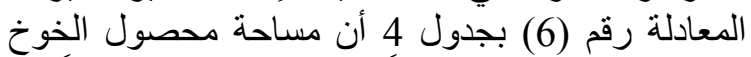
بمركز رفح تتناقص سنوياً بمقدار معنوي إحصائياً بلغ

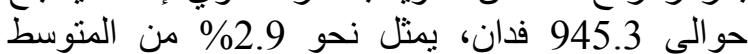
السنوي العام. وتثير التقديرات أن معامل التحديد قد بلغ

نحو 0.51.

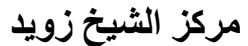

تثثير النتائج الواردة بجدول 3 بأن مساحة محصول الخوخ بمركز الثنيخ زويد قد بلغت حداردا الأدنى حوالي

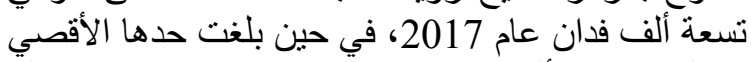

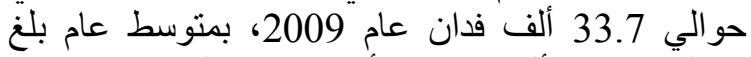
حوالي 20.5 ألف فدان. يأتي مركز الثيخ زويد في في لئ

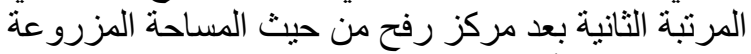

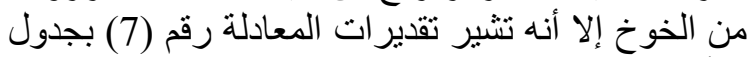

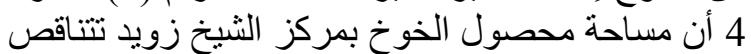

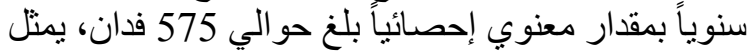

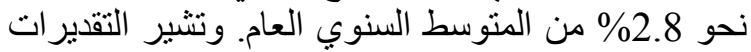
أن معامل التحديد قد بلغ نحو 0.26.

مركز بئر العبد

تنثير النتائج الواردة بجدول 3 بأن مساحة محصول العادئ الخوخ بمركز بئر العبد قد بلغت حدها الأدنى حوالئ حالي

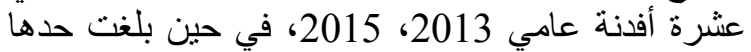

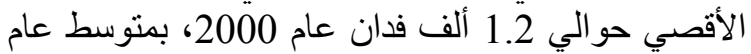
بلغ حوالي 487.2 فدان. كما تثنير تقدير ات المعاد المعادلة رقم

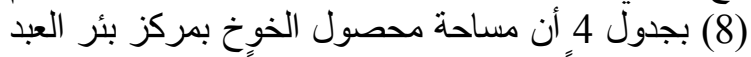
تتناقص سنوياً بمقار معنوي إحصائياً بلغ حو الي 74.3 فدان، يمثل نحو 15.3\% من الكتوسط السنوي العام. وتثير التقنيرات أن معامل التحديد قد بلغ نحو 0.94.

\section{مركز الحسنة}

تثشير النتائج الواردة بجدول 3 بأن مساحة محصول

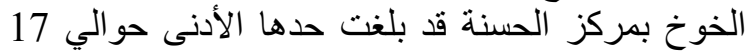

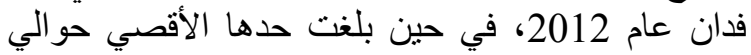
410 فدان عام 2000، فير، بمتوسط عام بلغ حوالي 67.2

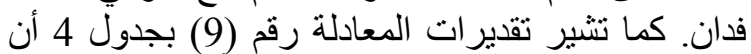

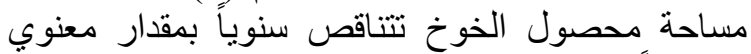

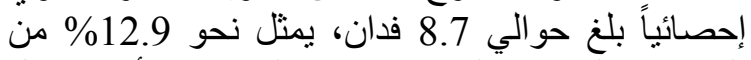

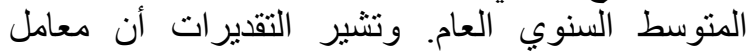
التحديد قد بلغ نحو 0.26. 
جدول 5. الأهمية النسبية للمساحة المثمرة لمحصول الخوخ وعدد الحائزين ومتوسط نصيب الحائز والوسط الهندسي

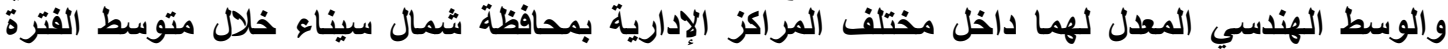

.(2017-2014)

\begin{tabular}{|c|c|c|c|c|c|c|c|}
\hline \multirow{2}{*}{ الوسط المعل (\%) } & \multirow{2}{*}{ الوسط الهندسي } & \multirow{2}{*}{ متوسط نصيب } & \multicolumn{2}{|c|}{ عدد الحائزين } & \multicolumn{2}{|c|}{ المساحة المثرة } & \multirow{2}{*}{ الادارى } \\
\hline & & & $(\%)$ & (حائز) & $(\%)$ & (فُان) & \\
\hline 58.24 & 57.82 & 3.59 & 53.91 & 6487 & 62.02 & 23289 & رفح \\
\hline 38.97 & 38.69 & 2.76 & 41.12 & 4948 & 36.40 & 13670 & الثيخ زويد \\
\hline 2.44 & 2.42 & 1.12 & 4.03 & 485 & 1.45 & 543 & العريش \\
\hline 0.33 & 0.33 & 0.41 & 0.89 & 107 & 0.12 & 44 & الحسنة \\
\hline 0.02 & 0.02 & 0.71 & 0.06 & 7 & 0.01 & 5 & بئر العبد \\
\hline 100 & 99.28 & 3.12 & 100 & 12034 & 100 & 37551 & جملة \\
\hline
\end{tabular}

المصدر: جُمعت وحُسبت من وزارة الزراعة واستصلاح الاراضي، مديرية الززراعة بشمال سبناء، سجلات قسم الفاكهة، بيانات غير منشورة، 2018.

تحتل المرتبة الرابعة من حيث عدد الحائزين، و البالغ

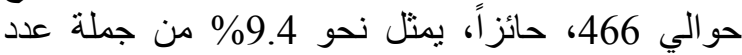

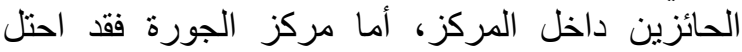

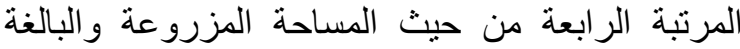

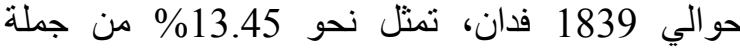
المساحة المزروعة داخل المركز، وتحتل المرتبة الثالثة

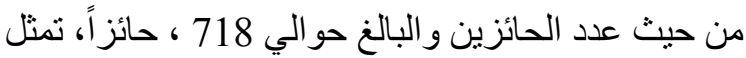

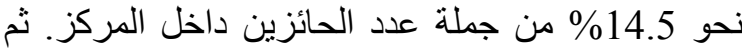
ياتي بعد ذلك في الترنيب قري العقور، أبوزرعي، التركي،

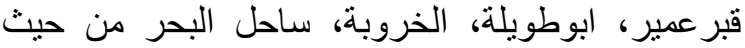

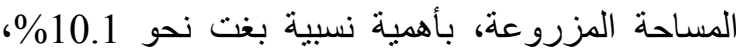

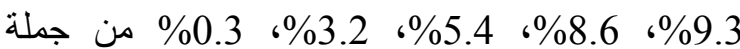
المساحة المنثرة داخل المركز و البالغة حوالي 13670 فدان. هذا وقد بلغ متوسط نصيب الحائز اقصى قيمة الحئ له له داخل قرية العقور بحو الي 4.8 فدان، مقابل حوالي الئ 1.1

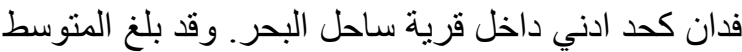

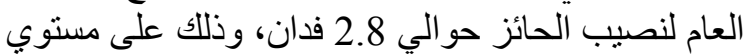
قري مركز الثيخ زويد. وتثير تقديرات الوسط الهين الهندي

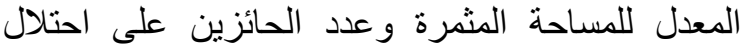

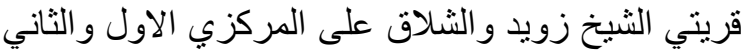

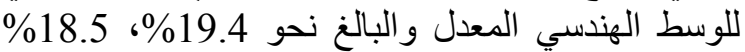
على الترتيب، لذا فقد تم اختيار هاتين القريتين لتمثيل مركز الثيخ زويد داخل عينة الدراسة.

\section{تحديد حجم العينة من محصول الذوخ في شمال سيناء}

تم تقدير حجم العينة الاجمالي والبالغ حوالي 180

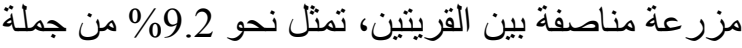

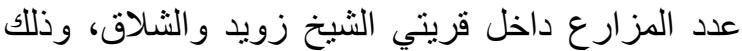
و وققا لتقدير ات المعادلة:
هذا وقد بلغ متوسط نصيب الحائز أقصي قيمة له حو الي 3.6 فدان داخل مركز رفحّ، مقابل حو اللي 0.41

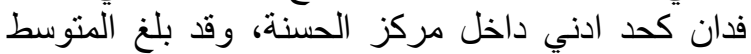

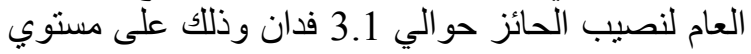
جملة مراكز المحافظة. وتشير تقدير التير ات الوسط الهندسي المعدل ان مركزي رفح والثيخ زويد يحتلان المرتبتان

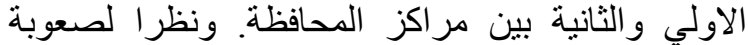

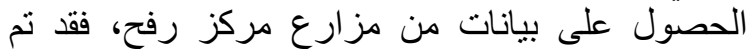
اختيار مركز الثيخ زويد لدراسة اقتصاديات إنتان إنتاج محصول الخوخ في شمال سيناء.

\section{اختيار قري العينة من محصول الخوخ داخل مركز الثيخ زويد}

وبوضح جدول 6 الأهمية النسبية للمساحة المثمرة و عدد الحائزين لمحصول الخوخ ومتوسط نصيب الحائز و الوسط الهندسي و الوسط الهندسي المعدل داخل لونل مختلف قري مركز الثيخ زويد بشمال سيناء خلال منوسط الفترة الفترة

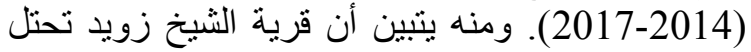

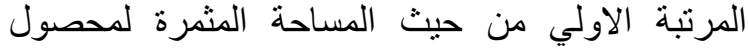

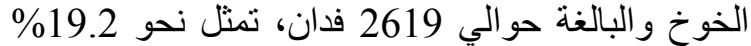
من جملة المساحة المثمرة داخل المركز، كمئل كما تحتل

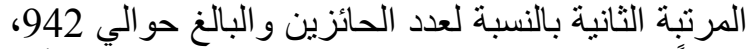

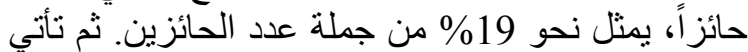
قرية الثلاق في المرتبة الثانية من حيث المساحة المثرة و البالغة حو الي 2204 فدان، تمثل نحو 16.1 \% من من جملة

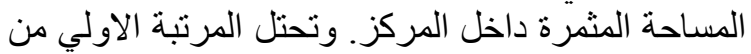

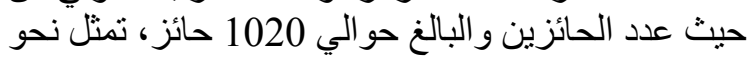
20.6\% من جملة عدد الحائزين داخل المركز.

وتحتل قرية الظهير المرتبة الثالثة من حيث المساحة

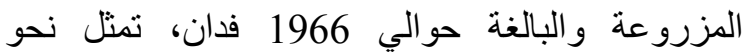
14.4\% من جملة المساحة المثمرة داخل المركز، كما 
جدول 6. الأهمية النسبية للمساحة المثمرة وعدد الحائزين لمحصول الخوخ ومتوسط نصيب الحائز والوسط الهندسي و الوسط الهنسي المعدل داخل مختلف قري مركز الثيخ زويد بثمال سيناء خلال متوسط الفترة (2014-2017).

\begin{tabular}{|c|c|c|c|c|c|c|c|}
\hline \multirow{2}{*}{ المعدل (الهندسي } & \multirow{2}{*}{$\begin{array}{c}\text { الوسط اللهندسي } \\
\text { (\%) }\end{array}$} & \multirow{2}{*}{ متوسط نصيب } & \multicolumn{2}{|c|}{ عدد الحائزين } & \multicolumn{2}{|c|}{ المساحة المثمرة } & \multirow{2}{*}{ الشيخ زيخ } \\
\hline & & & $(\%)$ & (حائز) & $(\%)$ & (ف) & \\
\hline 19.36 & 19.10 & 2.78 & 19.04 & 942 & 19.16 & 2619 & الشيخ زويد \\
\hline 18.48 & 18.23 & 2.16 & 20.61 & 1020 & 16.12 & 2204 & الشلاق \\
\hline 14.16 & 13.97 & 2.56 & 14.51 & 718 & 13.45 & 1839 & الجورة \\
\hline 11.80 & 11.64 & 4.22 & 9.42 & 466 & 14.38 & 1966 & الظهير \\
\hline 8.45 & 8.34 & 3.42 & 7.50 & 371 & 9.28 & 1269 & أبو زرعي \\
\hline 8.24 & 8.13 & 3.08 & 7.70 & 381 & 8.58 & 1173 & قبر عمير \\
\hline 7.85 & 7.75 & 4.76 & 5.90 & 292 & 10.17 & 1390 & العقور \\
\hline 6.22 & 6.14 & 2.11 & 7.03 & 348 & 5.37 & 734 & أبوطويلة \\
\hline 4.93 & 4.86 & 1.17 & 7.46 & 369 & 3.17 & 432 & الخروبة \\
\hline 0.52 & 0.51 & 1.08 & 0.83 & 41 & 0.32 & 44 & ساحل البحر \\
\hline 100 & 98.67 & 2.79 & 100 & 4948 & 100 & 13670 & جملة المركز \\
\hline
\end{tabular}

الحيازية بعينة الدراسة في محافظة شمال سيناء خلال منوسط الفترة (2020/2019) ومنه تبينة الارين فينة عدد مزارع العينة

تشير الأرقام الواردة بجدول 7 أن عدد مزارئه عارع العينة

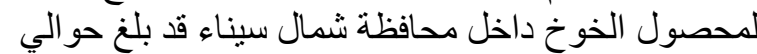

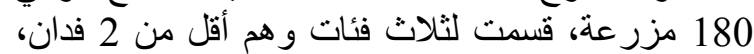

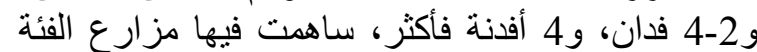

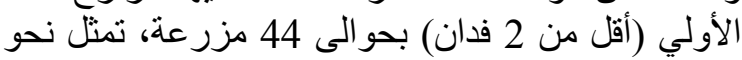

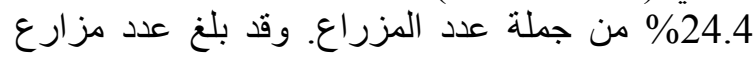

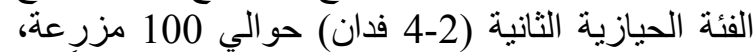

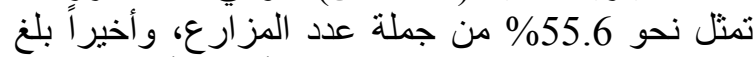

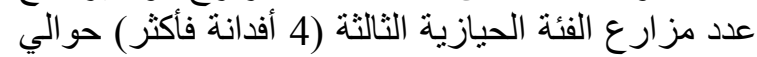

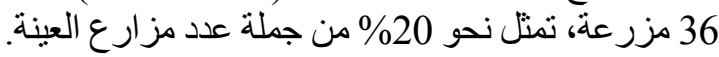

\section{الحيازة الفدانية}

أوضحت الأرقام الواردة بجدول 7 أن متوسط نصيب الخدابل

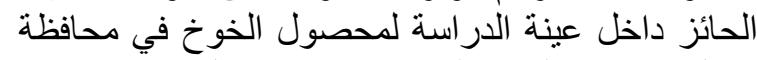

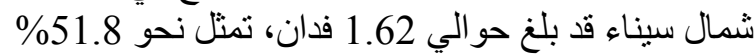
من منوسط جملة العينة، داخل الفئة الحيازية الأولي (أقلى

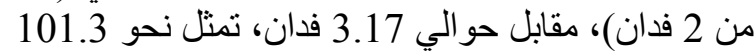
\% من متوسط جملة العينة، داخل الفئة الحيازية الثانية،

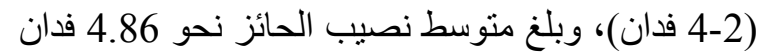
تمثل نحو 155.3\% من منوسط جملة العنة العينة، داخل الفئة

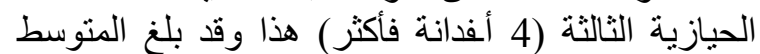

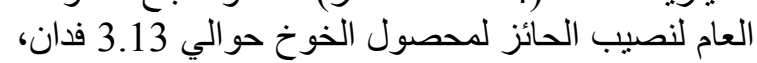

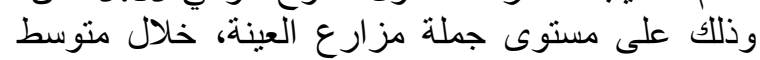
عامى (2020/2019).

$$
\mathrm{n}=\frac{\mathrm{N}}{(\mathrm{N}-1) \mathrm{B}^{2}+1}
$$

حيث أن: n = حجم العينة الممثلة للمجتمع أو الحائزين. = = جملة مجتمع الحائزين لمحصول الخوخ موضع الدر اسة.

$$
\text { B = تطأ التقدير (0.10). }
$$

توصيف عينة الاراسة لمزارع إنتاج محصول. لمارل

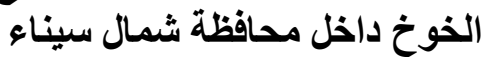

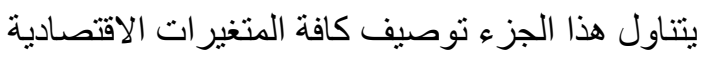

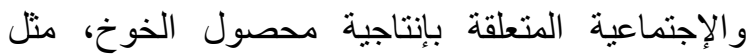

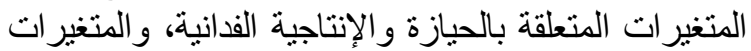

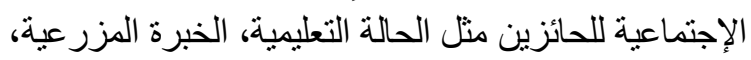

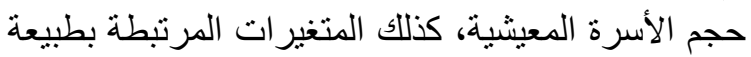

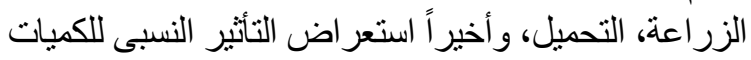

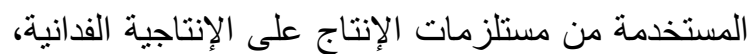
وذلك خلال متوسط عامى (2019/ 2020).

توصيف المتغيرات المرتبطة بالإنتاجية الفدانية لمحصول الخوخ داخل عينة الدراسة بونة

المتفيرات المرتبطة بعدد المزراع والحيازة والإنتاجية الفدانية

يوضح جدول 7 الأهمية النسبية لعدد مزار ع محصول الخوخ ومتوسط نصيب الحائز داخل مختلف الفئات 
جدول 7. الأهمية النسبية لعدد مزارع الخوخ ومتوسط نصيب الحائز داخل مختلف الفئات الحيازية بعينة الدراسة في محافظة شمال سيناء خلال متوسط العاد العي (2020/2019).

\begin{tabular}{|c|c|c|c|c|}
\hline الأهمية النسبية (\%) & متوسط نصيب الحائز (فدان) & الأهمية النسبية (\%) & عدد المزراع & الفئات الحيازية \\
\hline 51.8 & 1.62 & 24.4 & 44 & الفئة الأولي (أقلّل من 2 فُان) \\
\hline 101.3 & 3.17 & 55.6 & 100 & الفئة الثانية (2-4 فدان) \\
\hline 155.3 & 4.86 & 20.0 & 36 & الفئة الثالثة (4 أفدانة فأكثر) \\
\hline 100 & 3.13 & 100 & 180 & جملة \\
\hline
\end{tabular}

المصدر: جُمعت وحُسبت من استمارات الاستبيان الخاصة بالدراسة الميدانية.

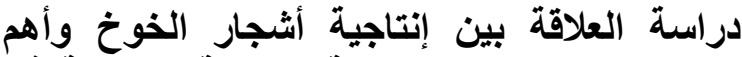
العوامل الموثرة عليها بعينة الاراسة المئة الميدانية في الخوخ شمال سيناء

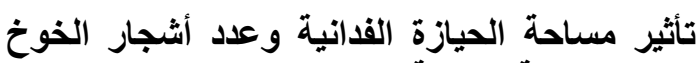
على الإنتاجية الفدانية

يوضح جدول 9 الأهمية النسبية لمساحة الحيازة الإنة الإنية الفدانية وعدد الأشجار في الفدان على الإتناجية الفذانية،

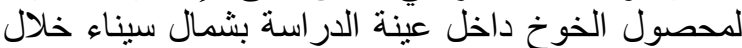

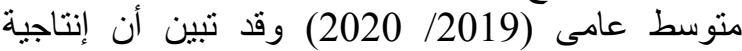

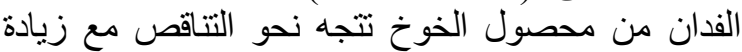

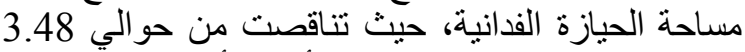
طن للفدان داخل الفئة الحيازية الأولي (أقل من فدانة) إلى دالى

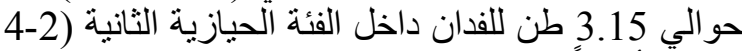

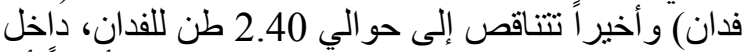

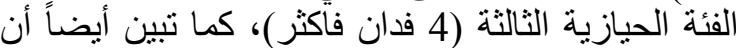

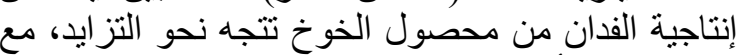

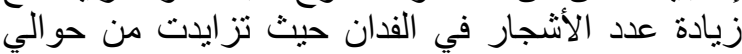

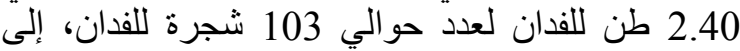
حو الي 3.48 طن للفدان لعدد حوالي 124 شجرة للفئ للفدان،

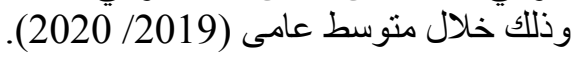

تأثير تحميل الزروع الحقلية على إنتاجية أشجار

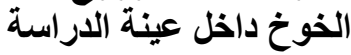

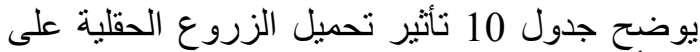

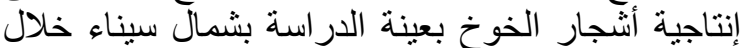

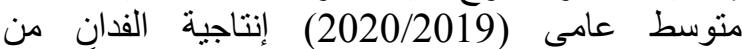
محصول الخوخ قد بلغت حوالي 3.51 طن سنوياً، تمثل نحو 111.4\% من متوسط الأنتاجية للفدان على مستوى الفي

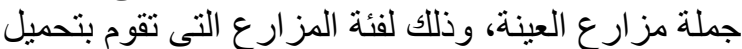

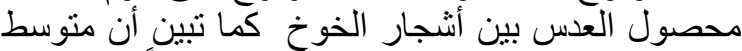

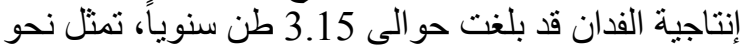
100\% من نظيرتها على مستوى جملة مز ارلي ارع العينة لفئة

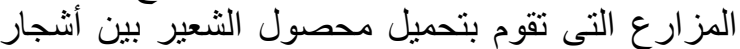

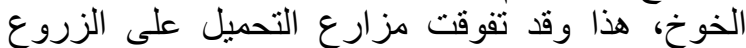
الحقلية على أشجار الخوخ خلف على نظيرتها غير المحملة، حيث بلغ متوسط إنتاجية الفدان بها حو الي 3.09 طن سنوياً.
المتفيرات المرتبطة بالإنتاجية الفدانية لمحصول الخوخ داخل عينة الدراسة الأبنة

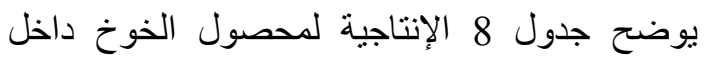
مختلف الفئات الحيازية بعينة الدراسة في شمال سيناء خلال متوسط عامى (2019/ 2020) حيث يتبين أن.

عدد الأشجار

بلغ منوسط عدد الأشجار في الفدان من محصول

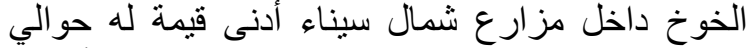

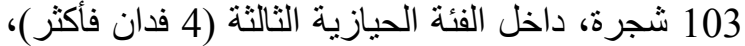
مقابل حو الي 124 شجرة كحد أقصى، داخل الفئة الحيازية

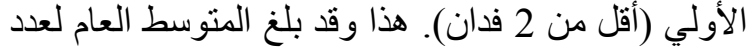
الأشجار في الفدان حو الي 120 شجرة، وذلان الك داخل جملة

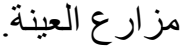

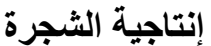

بلغ منوسط إنتاجية الثجرة لمحصول الخوخ داخل مزارع شمال سيناء أدنى قيمة لله حوالي 23.3 كيلو لئل

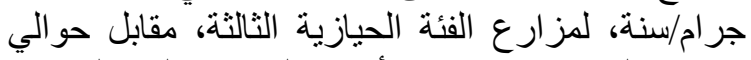

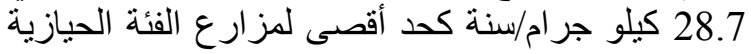

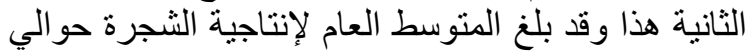

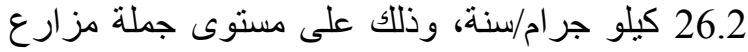
العينة، خلال متوسط عامى (2019/ 2020).

$$
\text { إنتاجية الفدان }
$$

بلغ متوسط إنتاجية الفدان من محصول الخوخ في لي لئي محافظة شمال سيناء أدنى قيمة له حونة حوالي 2.403 طن طن

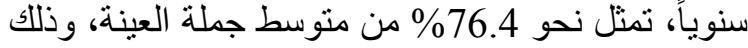

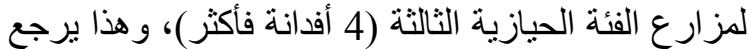
لإنخفلض انتاجية الثجرة الواحدة، مقابل حوالي 3.480

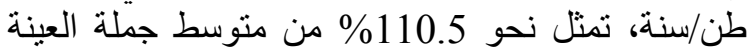
كدد أقصى، داخل الفئة الحيازية الأولي (أقل من 2 فندانة هذا وقد بلغ المنوسط العام لإنتاجية الفدان من محصول

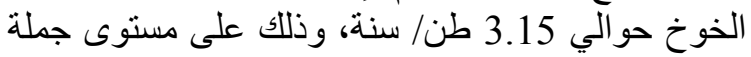
مز ارع العينة، خلال منوسط عامى (2019/ 2020). 
جدول 8. المؤشرات الإنتاجية لمحصول الخوخ داخل مختلف الفئات الحيازية بعينة الدراسة في محافظة شمال سيناء خلال منتوسط عامى (2020/2019).

\begin{tabular}{|c|c|c|c|c|}
\hline العام لإنتاجية الفدان & متوسط إنتاجية & الشجرة (كجم/سنية) & فتوسط الفدان عدد (شُشجرة) & الفئات الحيازية \\
\hline 110.5 & 3.480 & 28.1 & 124 & الفئة الأولي (أقل من 2 فدان) \\
\hline 103.9 & 3.270 & 28.7 & 114 & الفئة الثانية (2-4 فدان) \\
\hline 76.4 & 2.403 & 23.3 & 103 & الفئة الثالثة (4 أفدانة فأكثر) \\
\hline 100 & 3.15 & 26.2 & 120 & متوسط الفئات \\
\hline
\end{tabular}

المصدر: جُمعت وحُسبت من استمارات الاستبيان الخاصة بالدر اسة الميدانية.

جدول 9. تأثير مساحة الحيازة الفدانية لمحصول الخوخ داخل عينة الاراسة بشمال سيناء خلال متوسط عامي .(2020/2019)

\begin{tabular}{|c|c|c|}
\hline متوسط إنتاجية الفدان (طن) & عدد الأشُجار في الفدان (شجرة) & الفئات الحيازية \\
\hline 3.48 & 124 & ( أقل من 2 فدان) \\
\hline 3.270 & 114 & (4-2) \\
\hline 2.40 & 103 & (4 أفدانة فأكثر) \\
\hline 3.15 & 120 & جملة عدد الأشجار ومتوسط الإتتاجية \\
\hline
\end{tabular}

جدول 10. تأثير تحميل الزروع الحقلية على إنتاجية أشجار الخوخ بعينة الدراسة بشمال سيناء خلال متوسط عامي .(2020/2019)

\begin{tabular}{|c|c|c|}
\hline (\%) من المتوسط العام & متوسط إنتاجية الفدان (طن/سنة) & البيان \\
\hline 111.4 & 3.51 & التحميل بمحصول العدس \\
\hline 100 & 3.15 & التحميل بمحصول الشعير \\
\hline 98.1 & 3.09 & غياب التحميل \\
\hline 100 & 3.15 & متوسط جملة إنتاجية الفدان للعينة \\
\hline
\end{tabular}

تأثثير نوعية الطري المجاورة لمزارع الخوخ على الفئل إنتاجية الفدان بعينة الدراسة المجة

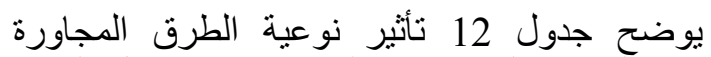

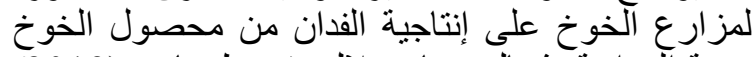

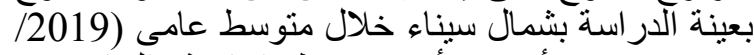

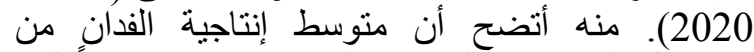
محصول الخوخ قد بلغت حوالي 3.49 طن سنويطاً لفئة الفئ

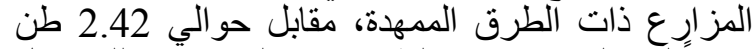

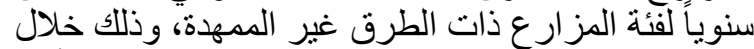

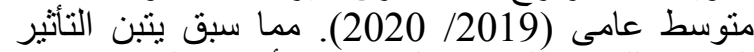

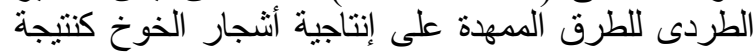
لتسهيل عمليات الخدمة مثل النقل وسر عة تسويق الإنتاج.
التأثير النسبى لطبيعة الزراعة (مجمعة أو مشتتة) على إنتاجية أثُجار الخوخ بعينة الدراسة:

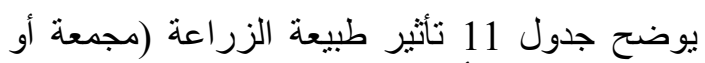
مشتتة) على إنتاجية أشجار الخوخ بأبر بعينة الدراسة بشمال

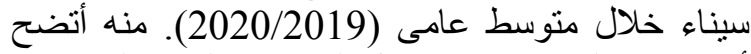

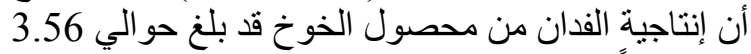

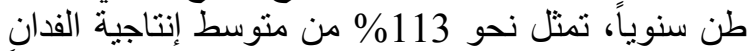

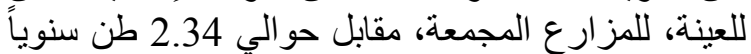
للفدان، تمثل 74.3\% من متوسط إنتاجية الفدان اللعينة

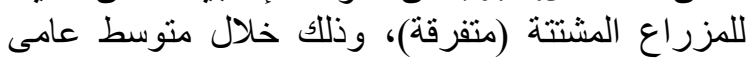
.(2020/2019) 
جلول 11. تأثير طبيعة الزراعة (مجمعة أو مشتتة) على إنتاجية أثجار الخوخ بعينة الاراسة بثمال سيناء خلال متوسط عامي (2020/2019).

\begin{tabular}{|c|c|c|}
\hline (\%) من المتوسط العام & متوسط إنتاجية الفدان (طن/سنة) & 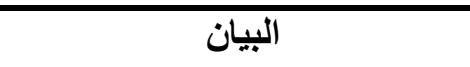 \\
\hline 113.0 & 3.56 & زراعة مجمعة \\
\hline 74.3 & 2.34 & زراعة متفرقة (مشتتة) \\
\hline 100 & 3.15 & متوسط جملة إنتاجية الفدان للعينة \\
\hline
\end{tabular}

جدول 12. تأثير نوعية الطرق المجاورة لمزارع الخوخ على إنتاجية الفدان من محصول الذوخ بعينة الدراسة بثمال سيناء خلال متوسط عامي (2020/2019)

\begin{tabular}{|c|c|c|}
\hline (\%) من المتوسط العام & متوسط إنتاجية الفدان (طن/سنة) & البيان \\
\hline 110.8 & 3.49 & طرق ممهدة \\
\hline 76.8 & 2.42 & طرق غير ممهدة \\
\hline 100 & 3.15 & متوسط جملة إنتاجية الفدان للعينة \\
\hline
\end{tabular}

102.9\% من نظيرتها على مستوى جملة المزارع، للفئة

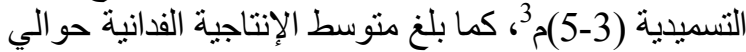

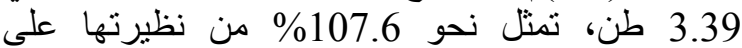

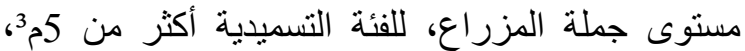

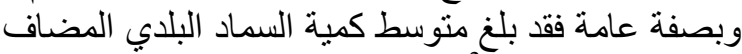

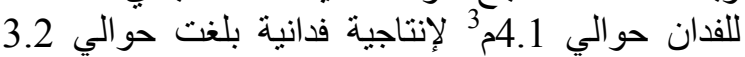

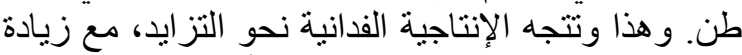

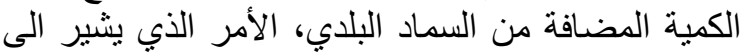

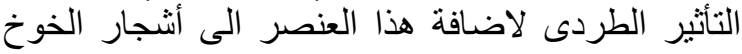

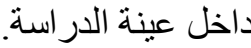
تأثير كمية المبيدات

أنثارت النتائج الموضحه بجدول 15 ان منوسط إنتاجية الفدان قد بلغت حوالي 2.86 طن، تمثل نحون النحو

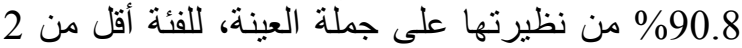
لتر ، كما بلغ متوسط الإنتاجية الفدانية حو الي 3.29 طن طن،

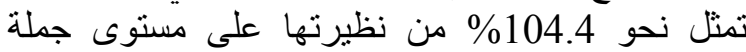

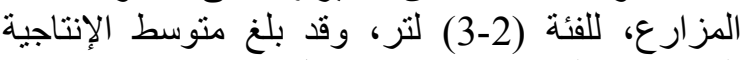

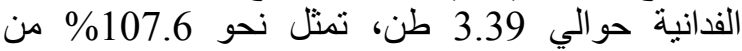

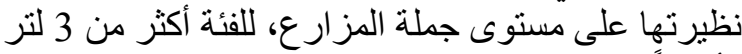

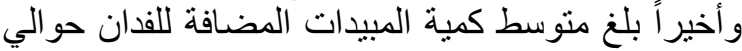

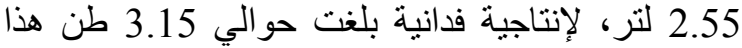

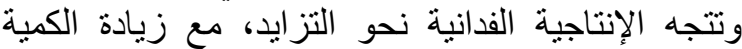

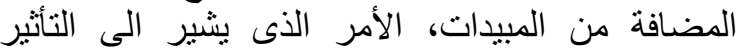
الطردى لاضافة هذا العنصر الى أشجار الخوخ لئن داخل

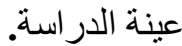

تأثير عناصر الإنتاج على إنتاجية الفدان من محصول الخوخ بعينة الاراسة الإنة علئ

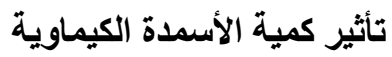
تشير الأرقام الواردة بجدول 13 أن إنتاجية الفدان من

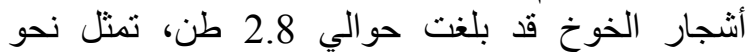

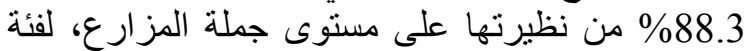
تسميدية أقل من 50 كجم، كما بلغيرت كلت الإنتاجية الفدانية

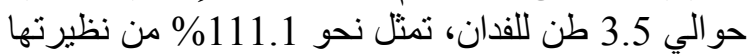
على مستوى جملة المزارع للفئة التسميدية (50-750)

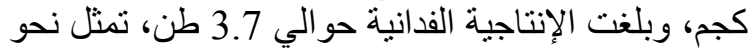
118.7 \% من نظيرتها على مستوى جملة المزار على للفئة التسميدية أكثر من 75 كجم. نظئ على

هذا وقد بلغ المتوسط العام لكمية السماد الكيماوي

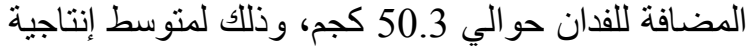

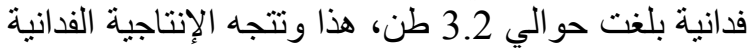

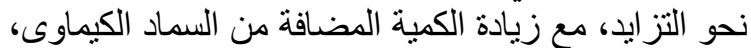

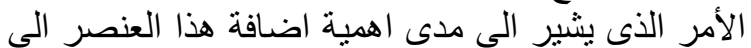

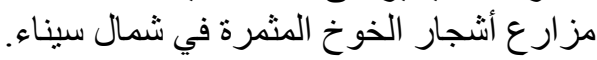

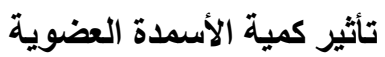

أكدت الأرقام الواردة بجدول 14 أن متوسط الإدئ إنتاجية

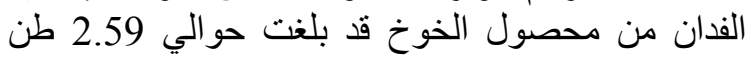

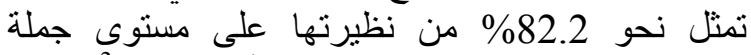

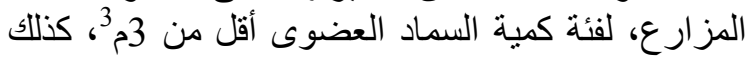
بلغ متوسط الإنتاجية الفدانية حو الي 3.24 طن، تمثل نحو 
جدول 13. تأثير كمية السماد الكيماوى المضاف على إنتاجية أشجار الخوخ داخل مزارع العينة خلال متوسط عامي

(2020/2019)

\begin{tabular}{|c|c|c|}
\hline (\%) من المتوسط العام & متوسط إنتاجية الفدان (طن/سنة) & فئات السماد الكيماوى (كجم/الفدان) \\
\hline 88.3 & 2.78 & أقَل من 50 كجم \\
\hline 111.1 & 3.50 & (75-50) كجم \\
\hline 118.7 & 3.74 & أكثر من 75 كجم \\
\hline 100 & 3.15 & متوسط جملة إنتاجية الفدان للعينة \\
\hline
\end{tabular}

متوسط كمية السماد الكيماوى المضاف للفدان 50.3 كجم

المصدر: جُمعت وحُسبت من استمار ات الاستبيان الخاصة بالدر اسة الميدانبة.

جدول 14. تأثير كمية السماد العضوى المضاف على إنتاجية الفدان من محصول الخوخ داخل مزارع العينة خلال متوسط

عامى (2020/2019)

\begin{tabular}{|c|c|c|}
\hline (\%) من المتوسط العام & متوسط إنتاجية الفدان (طن/سنة) & فئات السمـاد العضوى المضاف (م/فذان) \\
\hline 82.2 & 2.59 & أقل من 3 م 3 \\
\hline 102.9 & 3.24 & 3 م (5-3) \\
\hline 107.6 & 3.39 & 5 \\
\hline \multirow[t]{2}{*}{100} & 3.15 & جملة متوسط إنتاجية الفدان للعينة \\
\hline & & متوسط كمية السماد العضوى المضاف للقدان 4.10م3 \\
\hline
\end{tabular}

جدول 15. تأثير كمية المبيدات على إنتاجية الفدان من محصول الخوخ داخل مزارع العينة خلال متوسط عامي (2020/2019)

\begin{tabular}{|c|c|c|}
\hline \% من المتوسط العام & متوسط إنتاجية الفدان (طن/سنـة) & فئات كمية المبيدات (لتر/فذان) \\
\hline 90.8 & 2.86 & أقلّل من 2 لتر \\
\hline 104.4 & 3.29 & (3-2) لتر \\
\hline 107.6 & 3.39 & أكثر من 3 لتر \\
\hline \multirow[t]{2}{*}{100} & 3.15 & جملة متوسط إنتاجية الفدان للعينة \\
\hline & & متوسط كمية المبيدات المضافة للفدان2.55 لتر \\
\hline
\end{tabular}

الفدانية إلى حوالي 3.39 طن، تمثل نحو 107.6\% من من من من نظيرتها على مستوى جملة المزارع، للفئة أكثر من 10

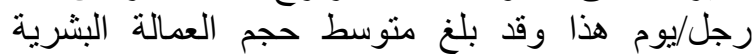

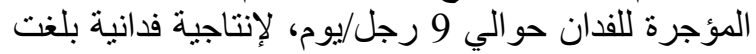

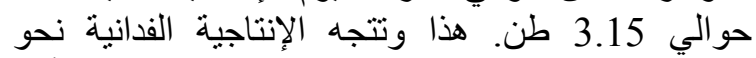

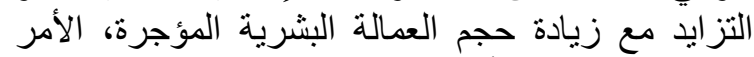

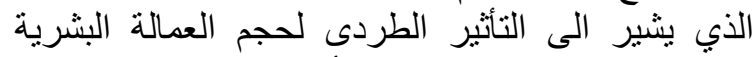
المؤجرة على الإنتاجية الفدانية لأشجار الخوخ.
تأثير حجم العمالة البشرية المؤجرة

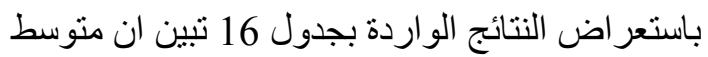

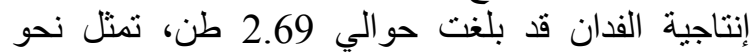

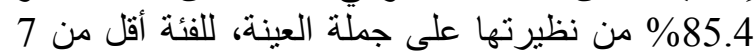
رجل/يوم، كما بلغت منوسط إنتاجية الفدان حوالي 3.22

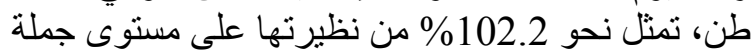

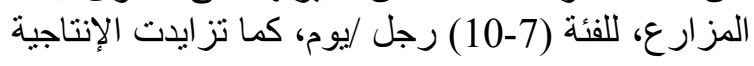


جدول 16. تأثير حجم العمالة البشرية المؤجرة على إنتاجية أشجار الخوخ داخل مزارع العينة خلال متوسط عامي

(2020/2019)

\begin{tabular}{|c|c|c|}
\hline (\%) من المتوسط العام & متوسط إنتاجية الفدان (طن/سنة) & فئات حجم العمالة البشرية للفدان (رجل / يوم) \\
\hline 85.4 & 2.69 & أقلّل من 7 رجل /يوم \\
\hline 102.2 & 3.22 & (10-7) رجل /يوم \\
\hline 107.6 & 3.39 & أكثر من10رجل /يوم \\
\hline 100 & 3.15 & جملة متوسط إنتاجية الفدان للعينة \\
\hline
\end{tabular}

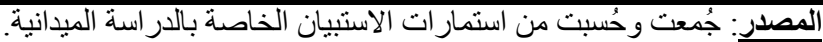

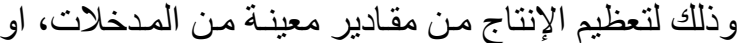

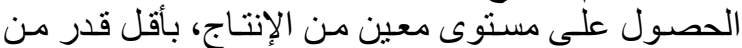

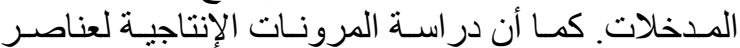

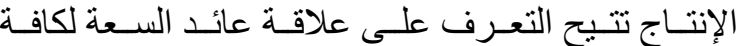

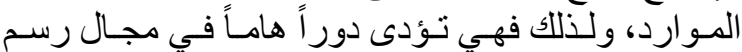

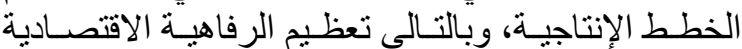

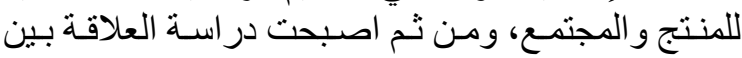

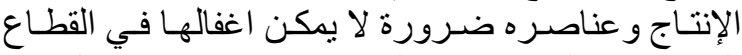

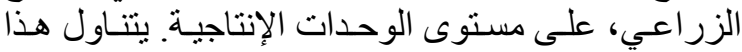

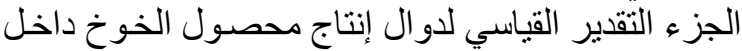

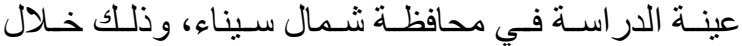

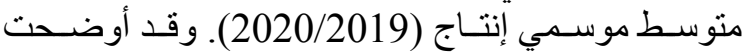

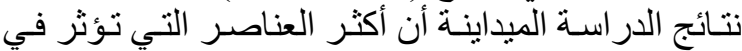

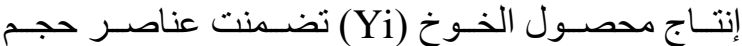

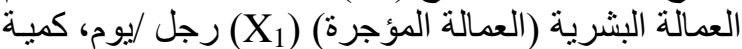

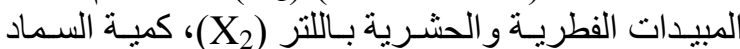

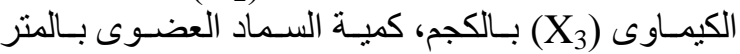

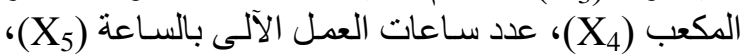

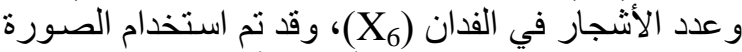

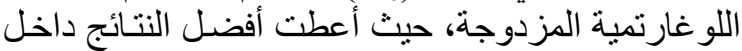

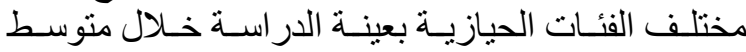
موسمى إنتاج (2019/ 2020).

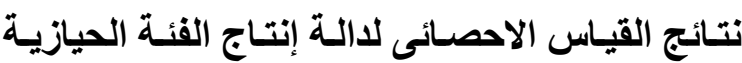
الأولي (أقل من فدان) داخل عينة الاراسة

القياس الاحصائى لدالـة إنتـاج الفئة الحيازيـة الأولي (أقل من فدان) داخل عينة الدراسة الداجة

وتوضح المعادلة رقم (12) بجدول 19 نتائج القياس

الإحصائي لدالة إنتاج الفئة الحيازية الأولي (أقلى من 2 فدان) داخل عينة الدراسة في محافظة شمال سيناء، خلال الإلة منوسط موسمى إنتاج (2020/2019)، وذللك باستخدام الانحدار المرحلى stepwise. وتشير النتائج المتحصل باجلئ عليها أن عامل حجم العمالة البشرية (العمالة المؤجرة)

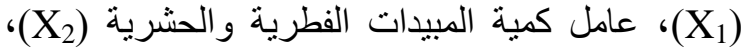

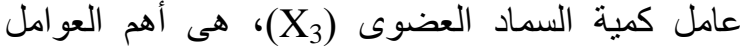
المؤثرة على الإنتاج على الترتيب.

\section{تأثير عدد ساعات العمل الآلى}

تشير النتائج الواردة بجدول 17 ان إنتاجية الفدان من

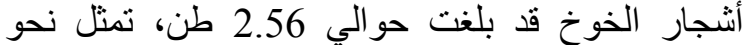

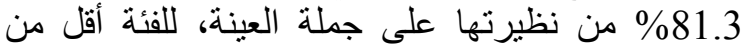
3ساعات، كما بلغت الإنتاجية الفدانية حو الي 3.31 طن طن،

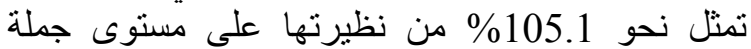
المز ارع للفئة (3-4) ساعات، كما بلغت الإنتاجية الفدانية

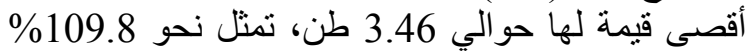

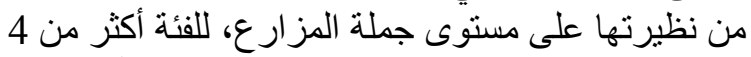

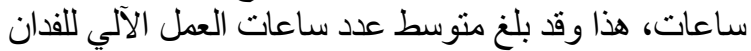
حو الي 3.2 ساعة لمتو سط إنتاجية بلغ حو الي 3.15 طن.

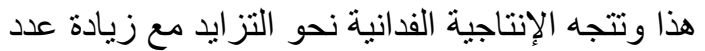

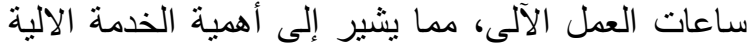
لزيادة إنتاجية محصول الخوخ.

تأثير عمر الأثجار

باستعر اض الأرقام الموضحة بجدول 18 تنين ان ان النيز

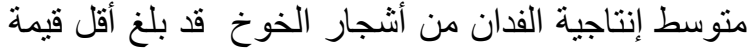

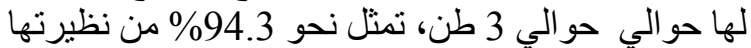
على مستوى جملة العينة، للفئة العمرية أقل من 15 سنة.ثم تزايدات الإنتاجية الفدانية لتصل إلى حوالى الئي 3.7

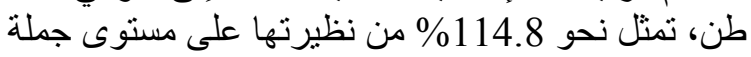

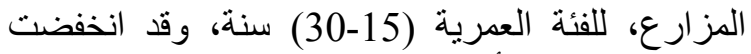
الإنتاجية الفدانية لأشجار الخوخ لتحنة لتصل إلى حوالي 2.3

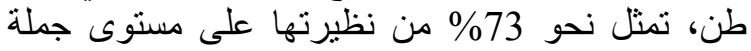
المزارع، وذلك داخل الفئة العمرية أكثر من 30 سنة سنة، هذا

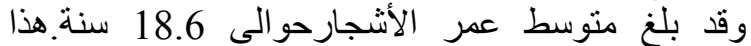

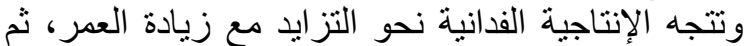

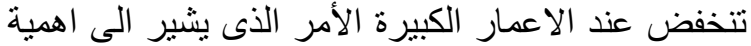

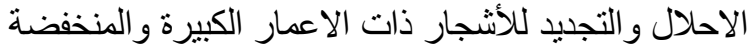

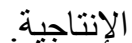

التقدير القياسى لاوال إنتاج محصول الخوخ داخل عينة الدراسة في محافظة شمال سيناء لأئاه

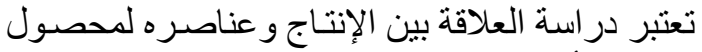

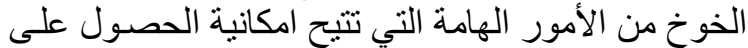

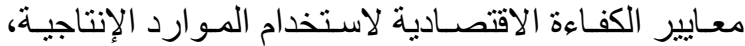


Abd El-Aziz, et al. | SINAI Journal of Applied Sciences 10 (2) $2021253-270$

جدول 17. تأثير عدد ساعات العمل الآلى على إنتاجية أثجار الخوخ المثمرة داخل مزارع العينة خلال متوسط عامى

(2020/2019)

\begin{tabular}{|c|c|c|}
\hline (\%) من المتوسط العام & متوسط إنتاجية الفدان (طن/سنة) & فئات عدد ساعات العمل الآلى (بالساعة) \\
\hline 81.3 & 2.56 & أقلّل من 3 ساعات \\
\hline 105.1 & 3.31 & (4-3) ساعة ) - (4) \\
\hline 109.8 & 3.46 & أكثر من4ساعات \\
\hline 100 & 3.15 & متوسط جملة إنتاجية الفدان للعينة \\
\hline \multicolumn{3}{|c|}{ متوسط عدد ساعات العمل الآلي 3.2 ساعة } \\
\hline
\end{tabular}

المصدر: جُمعت وحُسبت من استمارات الاستبيان الخاصة بالدراسة الميدانية.

جلول 18. تأثير عمر الأشجار على إنتاجية أشجار الخوخ المثرة داخل مزارع العينة خلال متوسط عامي (2019/ 2020 )

\begin{tabular}{|c|c|c|}
\hline (\%) من المتوسط العام & متوسط إنتاجية الفدان (طن/سنة) & فئَات عمر الأشجار (سنوات) \\
\hline 95.2 & 3.00 & أقل من 15 \\
\hline 124.4 & 3.92 & $(30-15)$ \\
\hline 73.7 & 2.32 & أكثر من 30 \\
\hline \multirow[t]{2}{*}{100} & 3.15 & متوسط جملة إنتاجية الفدان للعينة \\
\hline & سط عمر الشجرة 18.6 سنة & \\
\hline
\end{tabular}

جدول 19. نتائج القياس الإحصائي لاوال إنتاج محصول الخوخ داخل عينة الاراسة في محافظة شمال سيناء خلال متوسط موسمى إنتاج (2020/2019).

\begin{tabular}{|c|c|c|c|c|}
\hline $\begin{array}{c}\text { F } \\
\text { المحسوبة }\end{array}$ & $\mathbf{R}^{12}$ & التقدير القياسى لدالة الإتتاج & الحيازة الفدانية & المعادلة \\
\hline $83.5 * *$ & 0.81 & $\begin{aligned} \log \mathbf{Y}^{\wedge} \mathrm{i}= & 2.64+0.652 \log \mathbf{X}_{1}+0.426 \log \mathbf{X}_{2}+0.367 \log \mathbf{X}_{3} \\
& (2.26)^{* *}(6.78)^{* *}(4.23)^{* *} \quad(3.16)^{* *}\end{aligned}$ & (أقل من 2 فدانة الأولىى) & 13 \\
\hline
\end{tabular}

135.8** $0.86 \log \mathbf{Y}_{i}^{\wedge}=2.78+0.604 \log \mathbf{X}_{1}+0.396 \log \mathbf{X}_{2}+0.342 \log \mathbf{X}_{3} \quad$
$(2.54)^{*}(6.13)^{* *}$
$(3.68) * *$
$(3.12)^{*}$
(4) 2)

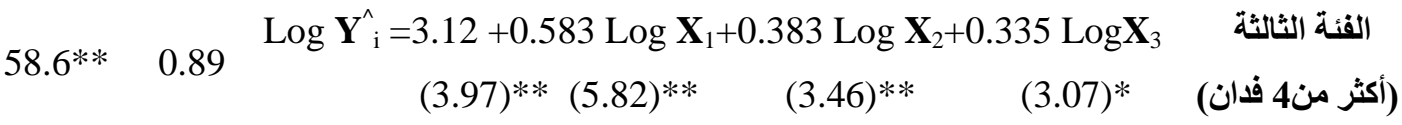
15

$$
(3.97)^{* *}(5.82)^{* *} \quad(3.46)^{* *} \quad(3.07)^{*} \quad \text { (أكثر من4 فدان) }
$$

14

القيمة التقديرية لكمية إنتاج الفدان من محصول الخوخ بالطن في المشاهدة i $=\mathbf{Y}^{\wedge}{ }^{\wedge}$

القيمة التقديرية لحجم العمالة البشرية (رجل / يوم) للفدان في المشاهدة i

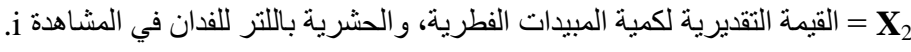

. القيمة التقديرية لكمية السماد العضوى بالمتر المكب في المشاهدة

44، للفئة الأولي، 100 للفئة الثانية،36 للفئة الثالثة.

... 3 ، 2 ، $1={ }^{\wedge} \mathbf{i}$

المصدر: نتائج الحاسب الآلى لبيانات الدر اسة الميدانية. 
القياس. كما تشير التقديرات أن المرونـة الإنتاجية لعوامل المبل

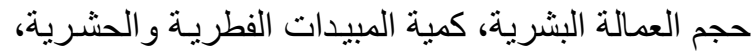

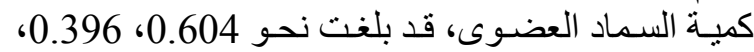
0.342 على الترتيب، الى أن مرونة هذه العناصر تعكس

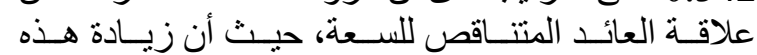

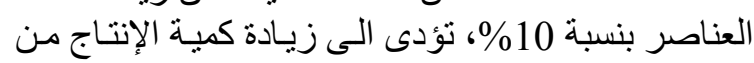

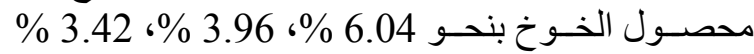

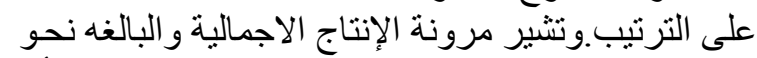

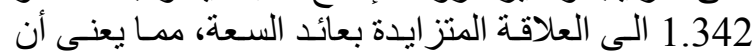

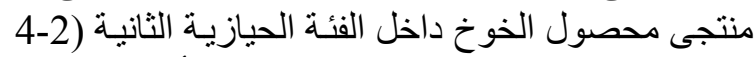

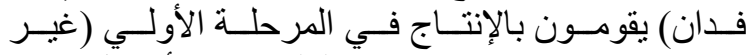

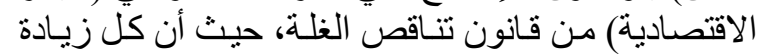

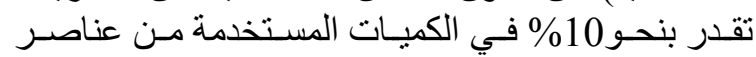

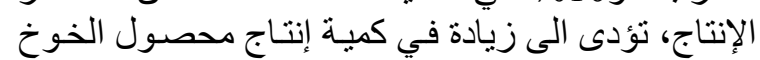

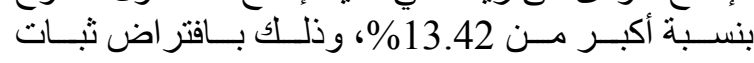

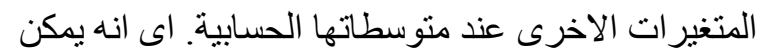

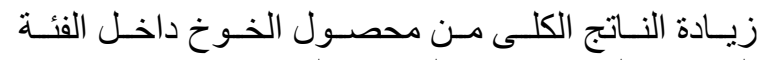

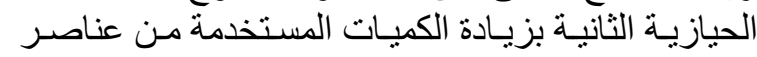

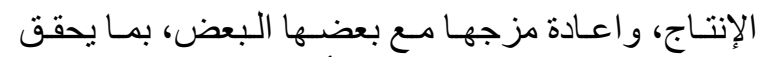

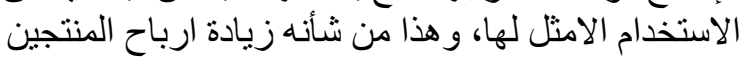

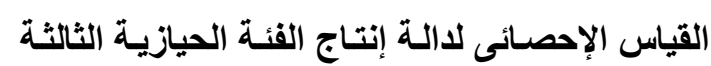

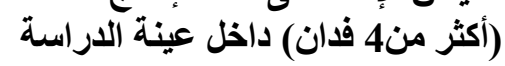

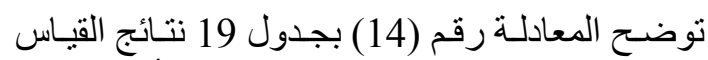

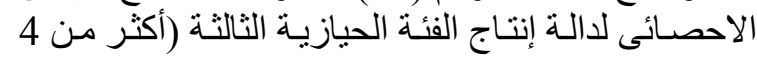

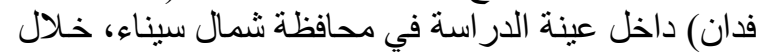

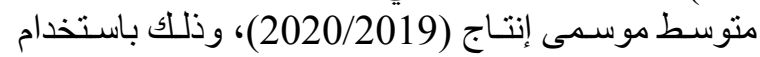

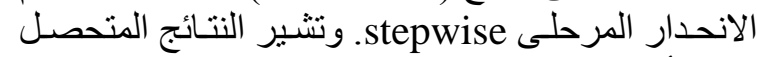

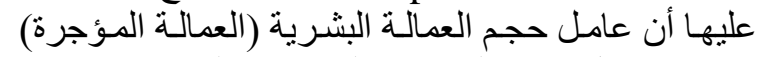

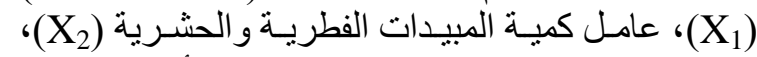

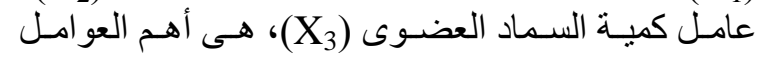
الؤثرة على الإنتاج على الترتيب.

كما تشير التقدير ات المتحصل عليها التها أن معامل التحديد

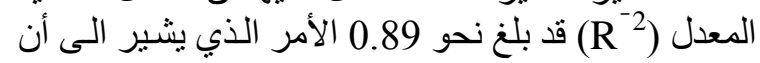

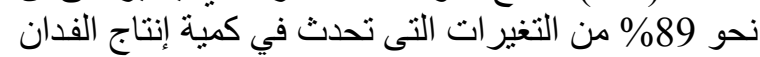

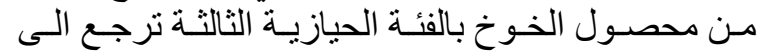

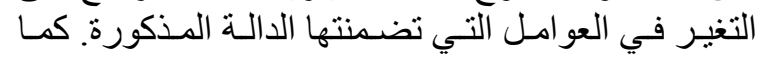

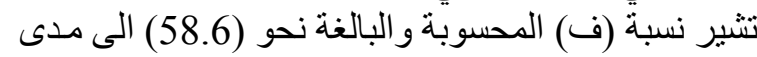
مطابقة النموذج المستخدم لطبيعة البيانات موضع القياس.

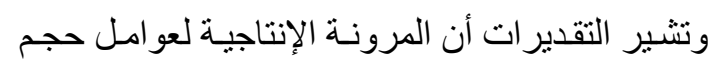

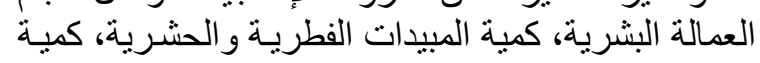

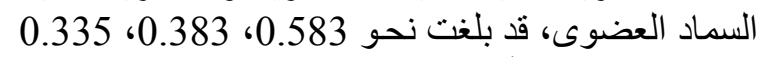

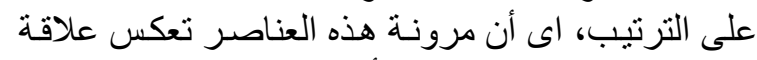

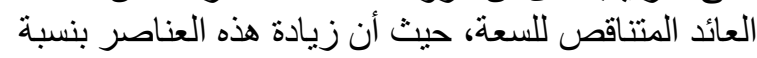

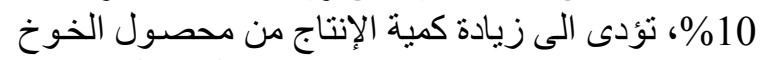

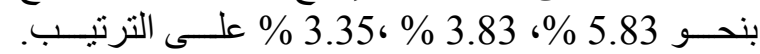
وتثير مرونة الإتناج الاجمالية و البالغهـ نحو 1.301 الى لى
وتشير التقدير ات المتحصل عليها أن معامل التحديد

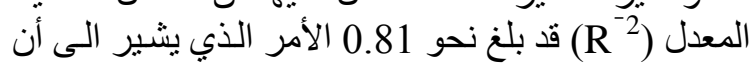
نحو 81\% من التغير ات التي تحدث في كمية إنتاج الفدان

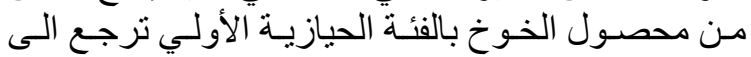

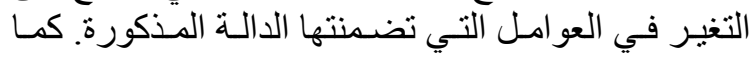

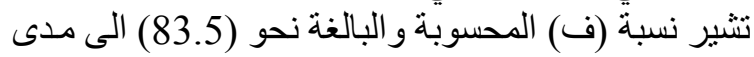

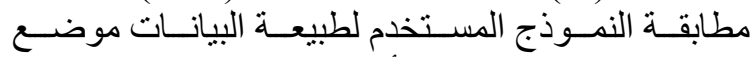

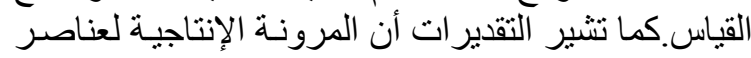

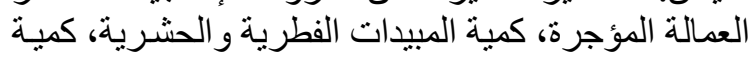

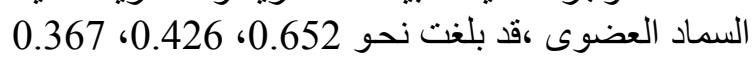

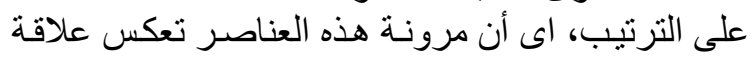

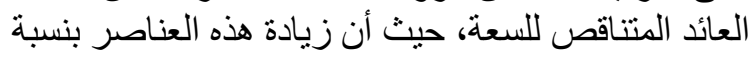

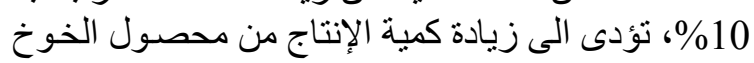

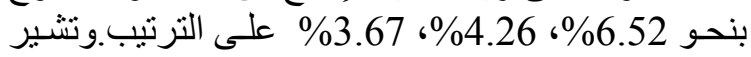

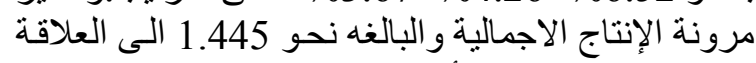

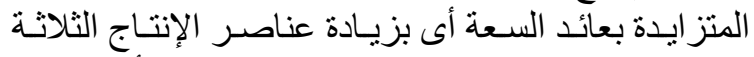

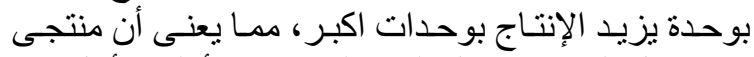

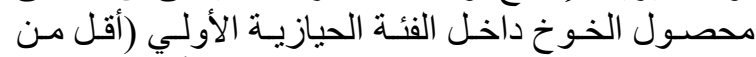

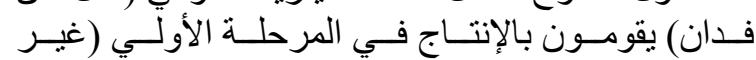

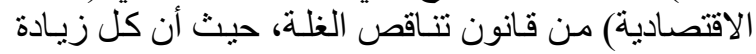

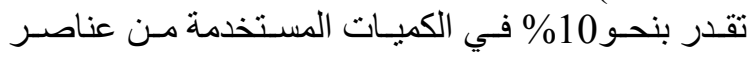

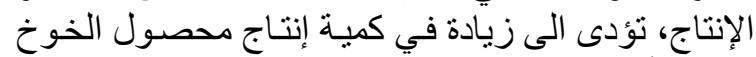

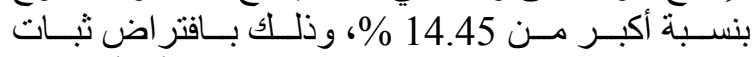

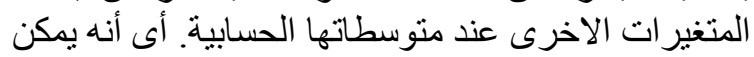

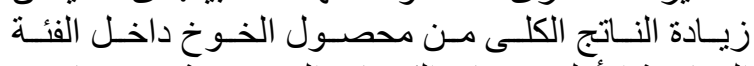

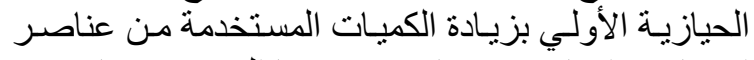

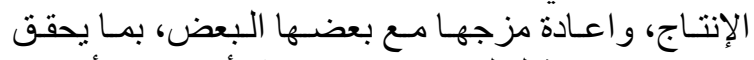

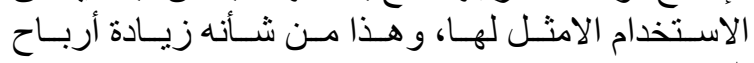

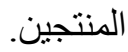

\section{نتائج القياس الإحصـائى لدالـة إنتاج الفئسة الحيازيـة الثانية (4-2) فذان داخل عينة الأراسة لئة}

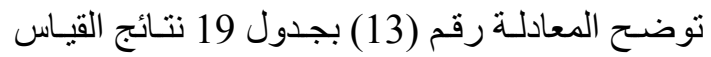

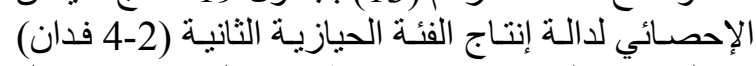

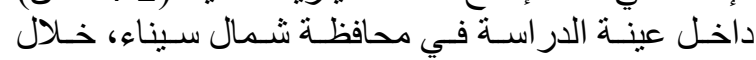
منوسط موسـى إنتـاج (2020/2019)، وذلك باسـتخدام

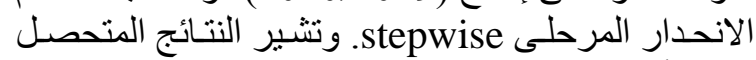

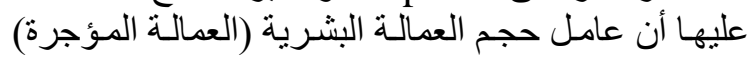

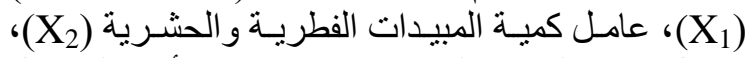

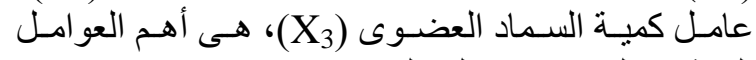
المؤثرة على الإنتاج على الترتيب.

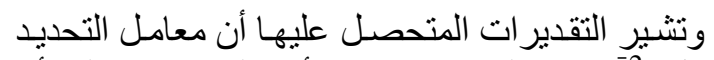

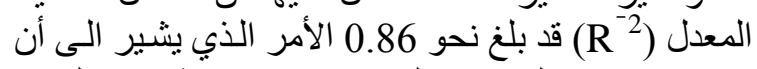
نحو 86\% من التغير ات التي تحدث في كمية إنتاج الفدان

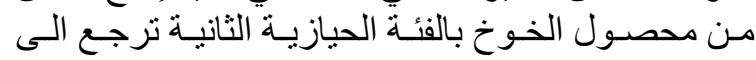

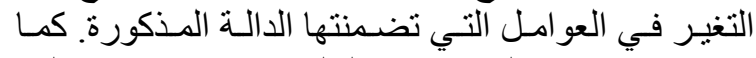

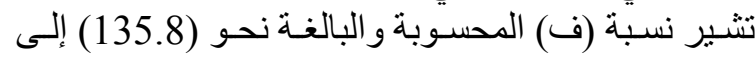

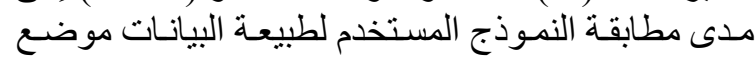


الفعلي للإنتاج بحو الي 1.34 طن، مما يشير إلى أنه لتقليل

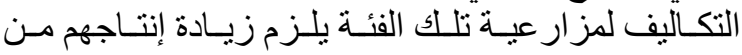
الخوخ.

بعنة الداليف إنتاج الفئة الحيازيـة الثانيـة (2-2 فدان)

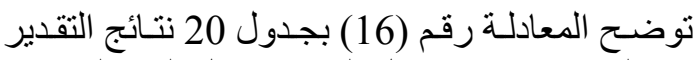

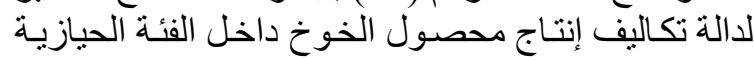

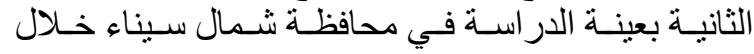

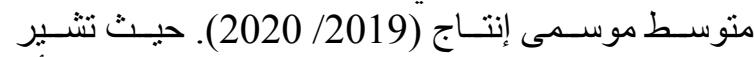

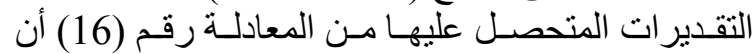

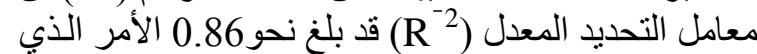

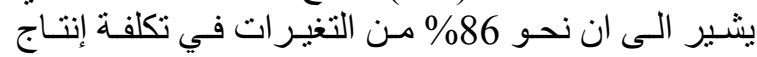

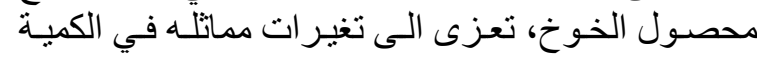

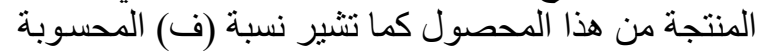

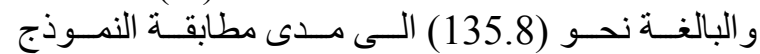

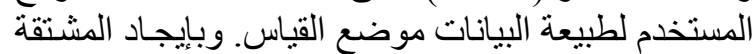

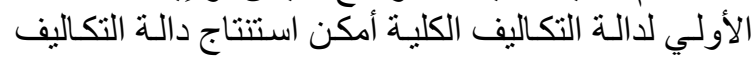

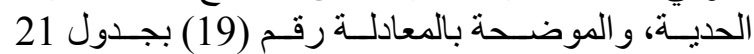

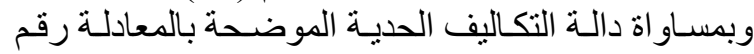

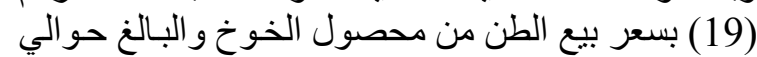

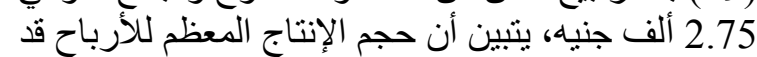

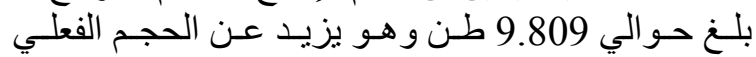

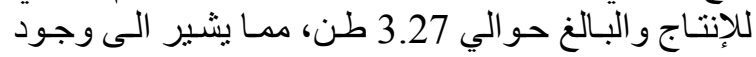

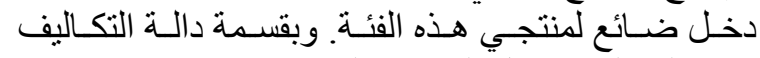

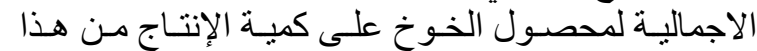

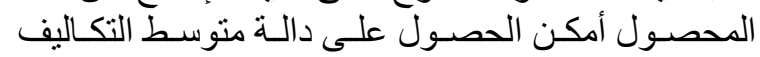

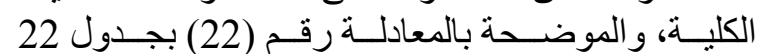

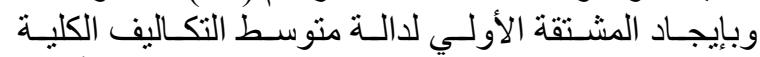

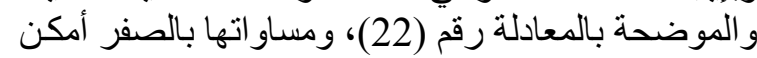

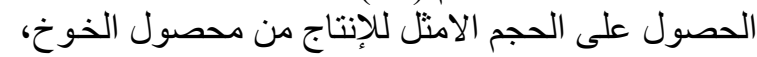

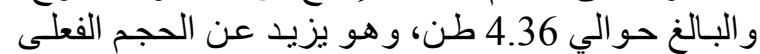

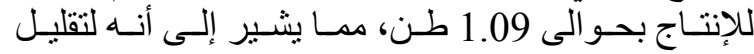

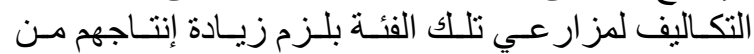

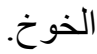

\section{دالة تكاليف إنتاج الفئة الحيازيـة الثالثة (أكثر من4 فدان) بعينة الدراسة}

توضـح المعادلـة رقم (17) بجدول 20 نتـائج التقدير

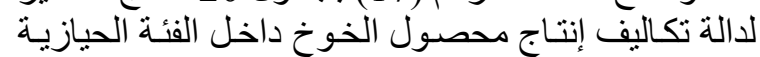

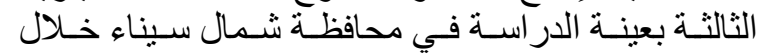

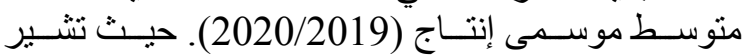

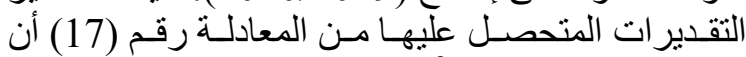

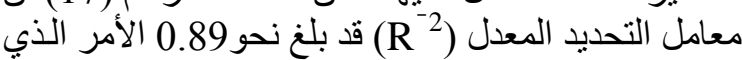

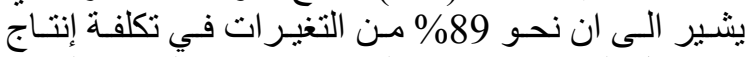
محصول اليوسفي، تعزى الى تلى تغير ات مماثلّه في الكميـة

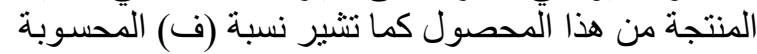

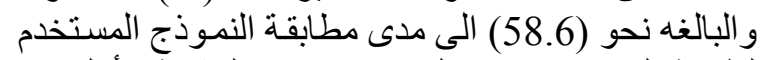

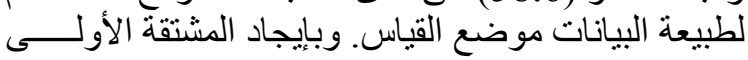

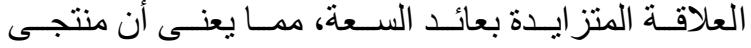

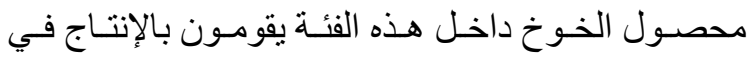

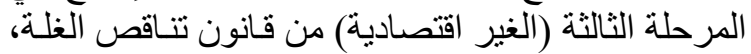

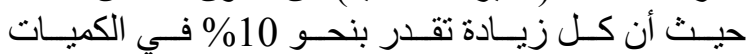

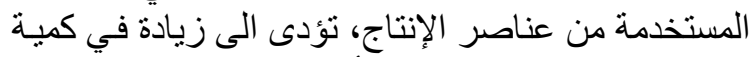

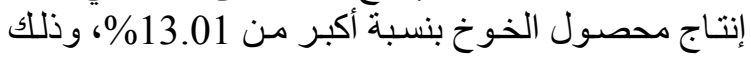

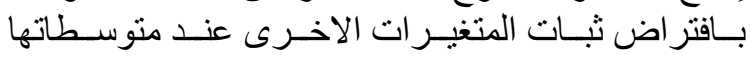

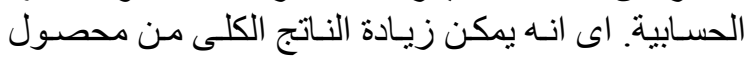

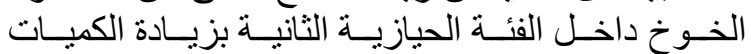

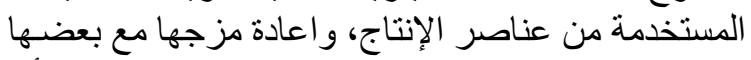
البععض، بما يحقق الاستخدام الامثل لها، وهذا وهذا من شـأنه

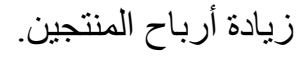

\section{التحليل الاقتصادي لتكاليف إنتاج محصول الخوخ

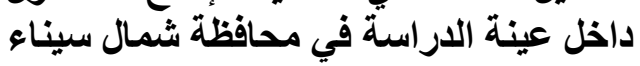

يتناول هذا الجزء التحليل القياسى لدول تكاليف إنتاج

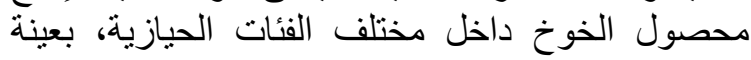

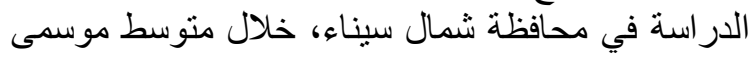
إنتاج (2019/ 2020).

\section{دالة تكاليف إنتاج الفئة الحيازية الأولي (أقل من 2

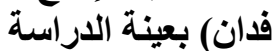

توضـح المعادلة رقم (15) بجدول 20 نتائج التقدير

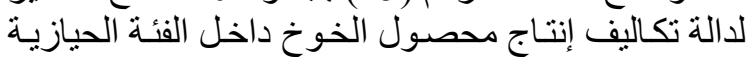
الأولي (أقل من 2 فدان) بعينة الدر استة في محافظـة شمال

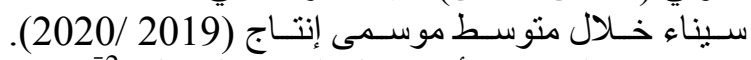

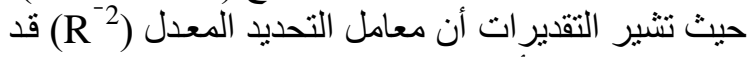

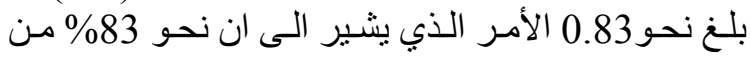

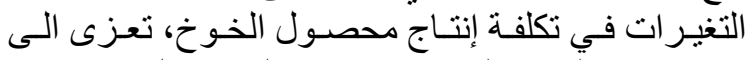

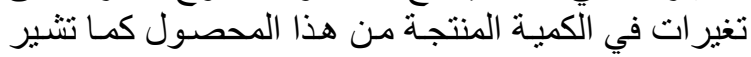

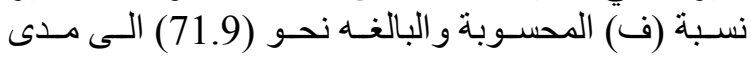
مطابقة النموذج المستخدم لطبيعة البيانات موضية البـع القياس. وبايجاد المشتقة الأولي لدالة التكاليف الكلية أمكن استنتاج

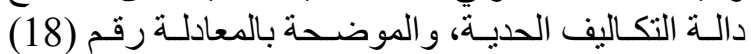

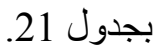

وبمساو اة دالة التكاليف الحدية الموضحة بالمعادلة رقم

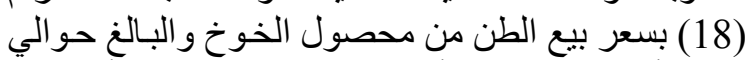

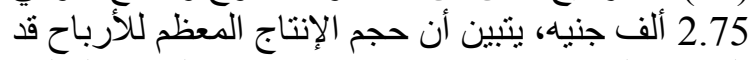

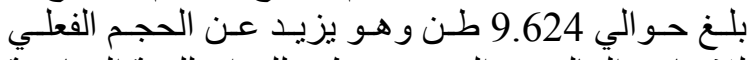

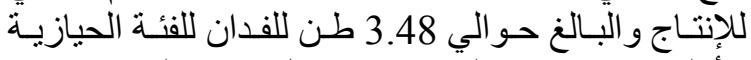

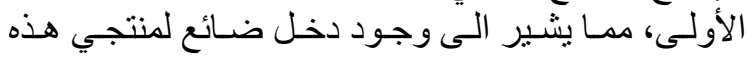

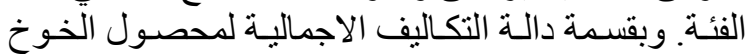

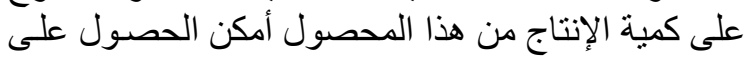

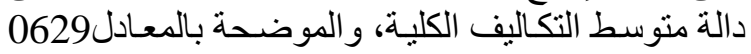

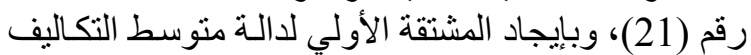

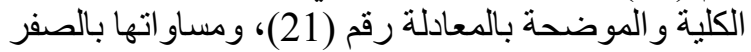

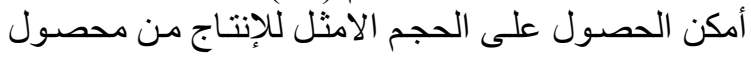
الخوخ، و البالغ حوالي 4.82 طن، و هو يزيد لإنيد عن الحجم 
جدول رقم (20): النماذج القياسية لدوال تكاليف الإجمالية لمحصول الخوخ داخل عينة الدراسة في محافظة شمال سيناء خلال متوسط موسمى إنتاج (2020/2019).

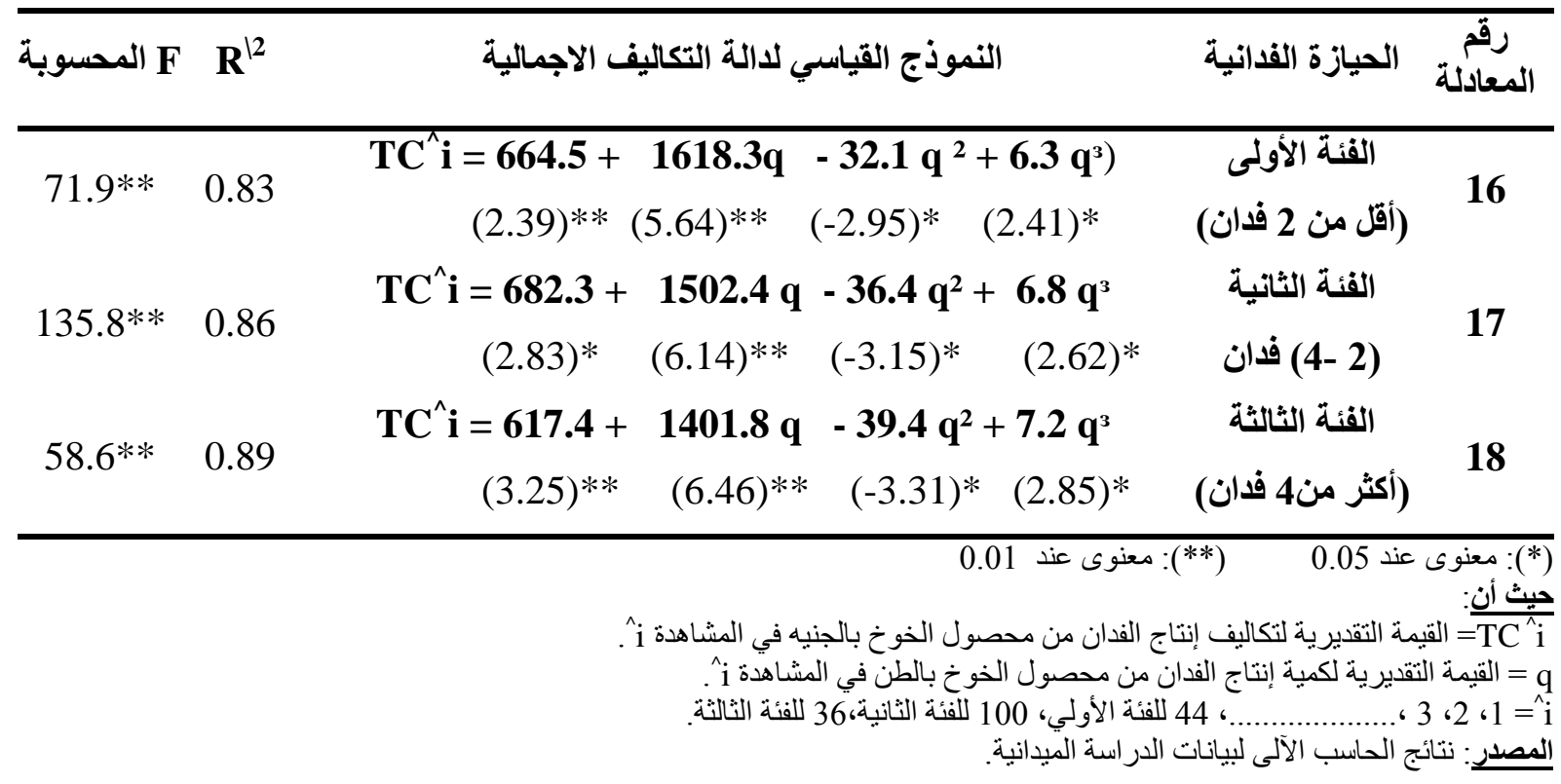

جدول 21. النماذج القياسية لاوال التكاليف الحدية لمحصول الخوخ داخل عينة الاراسة في محافظة شمال سيناء خلال متوسط موسمى إنتاج (2020/2019)

\begin{tabular}{|c|c|c|}
\hline دالة التكاليف الحدية & الفئات الحيازية & رقم المعادلة \\
\hline $\mathrm{MC}^{\wedge} \mathrm{i}=1618.3-64.29 \mathrm{q}^{1}+18.9 \mathrm{q}^{2}$ & الفئة الأولى (أقل من 2 فدان) & 19 \\
\hline $\mathrm{MC}^{\wedge} \mathrm{i}=1502.4-72.8 \mathrm{q}^{1}+20.4 \mathrm{q}^{2}$ & الفئة الثانية (2 -4) فدان & 20 \\
\hline $\mathrm{MC}^{\wedge} \mathrm{i}=1401.8-78.8 \mathrm{q}^{1}+21.6 \mathrm{q}^{2}$ & الفئة الثالثة (أكثر من4 فذان) & 21 \\
\hline
\end{tabular}

Mci

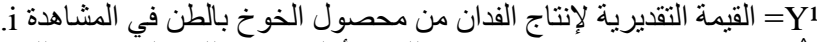

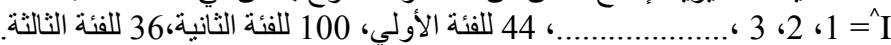

المصدر: جُمعت وحُسبت من المعادلات الواردة بجدول 21.

جدول 22. النماذج القياسية لدوال متوسط التكاليف الكلية لمحصول الخوخ داخل عينة الدراسة في محافظة شمال سيناء خلال متوسط موسمى إنتاج (2020/2019)

\begin{tabular}{|c|c|c|}
\hline دالة متوسط التكاليف الكلية & الفئات الحيازية & رقم المعادلة \\
\hline $\mathbf{A T C}^{\wedge} \mathbf{i}=664.5 / \mathrm{q}+1618.3-32.1 \mathrm{q}^{1}+6.3 \mathrm{q}^{2}$ & الفئة الأولى (أقلّ من 2 فدان) & 22 \\
\hline $\mathbf{A T C}^{\wedge} \mathbf{i}=682.3 / \mathrm{q}+1502.4-36.4 \mathrm{q}^{1}+6.8 \mathrm{q}^{2}$ & الفئة الثانية (2-4) فذان & 23 \\
\hline $\mathbf{A T C}^{\wedge} \mathbf{i}=617.4+1401.8 q^{1}-39.4 q^{1}+7.2 q^{2}$ & الفئة الثالثة (أكثر من 4 فدان) & 24 \\
\hline 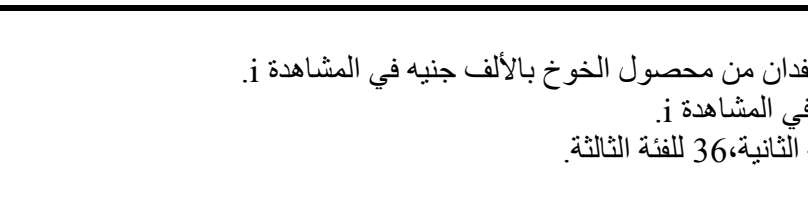 & 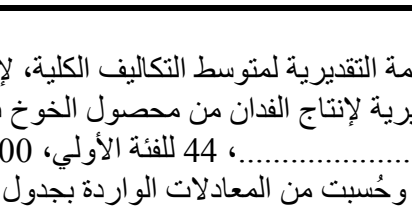 & 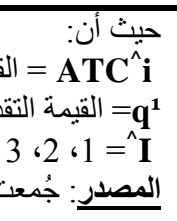 \\
\hline
\end{tabular}


2- الاهتمام بتحميل محاصيل العدس و الشعير على أشنار

$$
\text { الخوخ. }
$$

3- الاهتمام بنظام الزر اعة (مجمعة) لمحصول الخوخ.

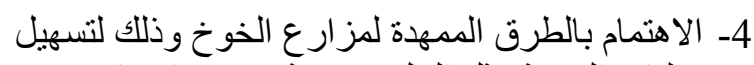

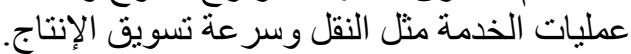

5- تطبيق بر امج التسميد الكيماوى لأشجار الخوخ.

$$
\text { 6- توفير العمالة البشرية المؤجرة. }
$$

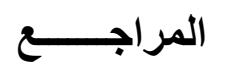

أبو الروس، أحمد محمود يوسف (2020). محاضرات

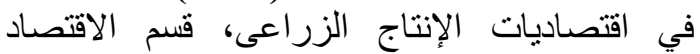
و الإرشاد الزراعى، كلية التكنولوجيا و التنمية، جامعة الإنات

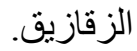

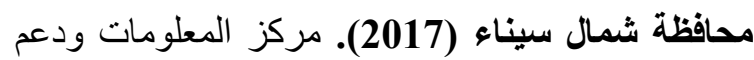
اتخاذ القرار، الكتاب الاحصائي، بيانات ثانوية غير

$$
\text { منشورة. }
$$

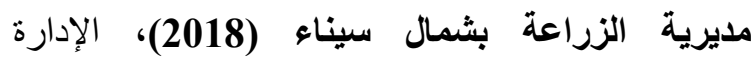
الزراعية لمركز الثيخ زويد، سجلات ادارة الفاكهة،

$$
\text { بيانات غير منشورة. }
$$

وزارة الزراعة واستصلاح الأراضي (2018). مديرية

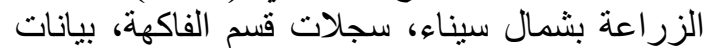

$$
\text { غير منشورة. }
$$

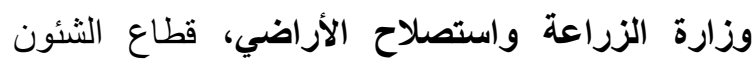

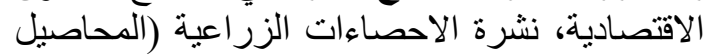
الصيفية والنيلية)، بيانات ثانوية غيرة الإنية منشورة، أعداد متفرقة.
لدالة التكاليف الكليـة أمكن استنتاج دالة التكاليف الحديـة،

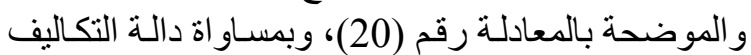

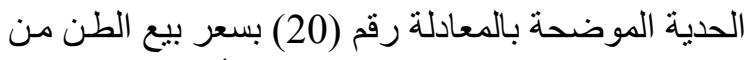
محصول اليوسفي و البالغ حو الي 2.75 ألف جنيها، يتبين بالفين

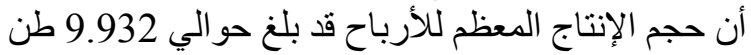

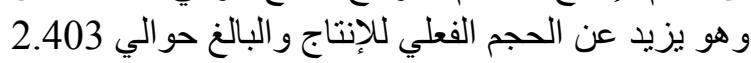

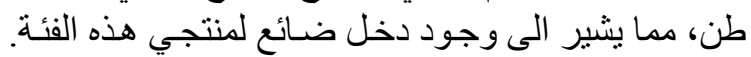

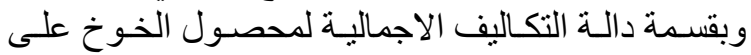

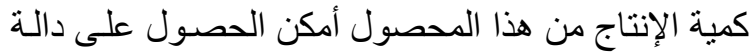

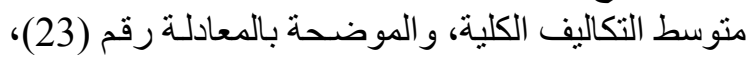

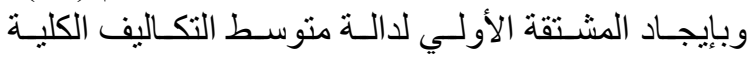

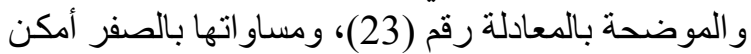

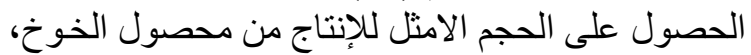

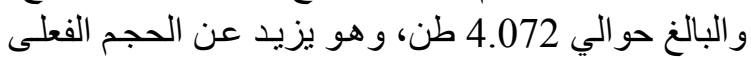

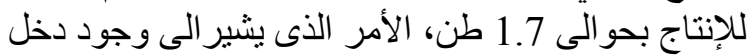

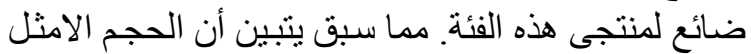

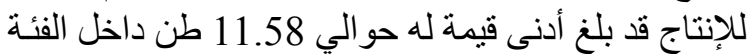

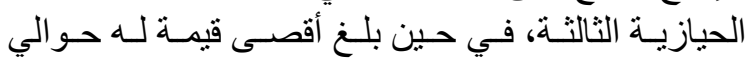

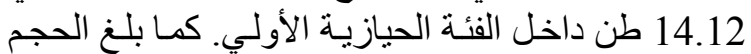

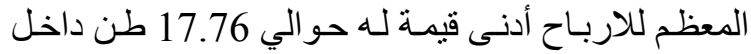

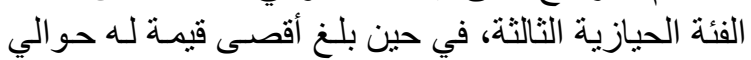

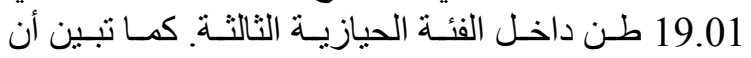

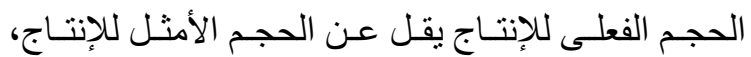

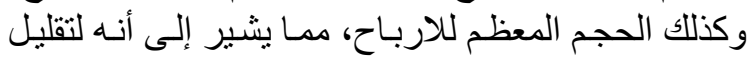

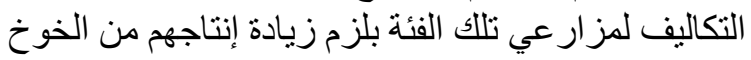
بمحافظة شمال سيناء. التوصيات: 1- أهية الاحلال والتجديد للأشجار ذات الاعمار الكبيرة و ونخفضة الإنتاجية. 


$$
\begin{aligned}
& \text { الملخص العربي } \\
& \text { دراسة الكفاءة الاقتصادية والإنتاجية لمحصول الخوخ في محافظة شمال سيناء } \\
& \text { سيد صلاح عبد العزيز *1، سعاد عبدالفتاح إبراهيم، رجب محمد حفني1، محمد كامل الريحان2 } 2
\end{aligned}
$$

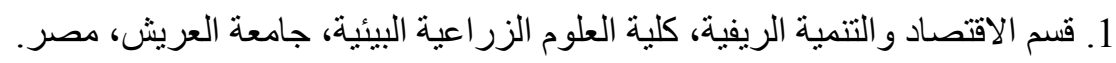

$$
\begin{aligned}
& \text { 2. قسم الاقتصاد، كلية الزر اعة، جامعة عين شمس، مصر الادهر. }
\end{aligned}
$$

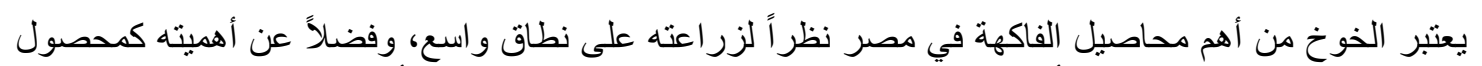

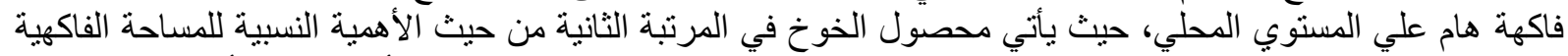

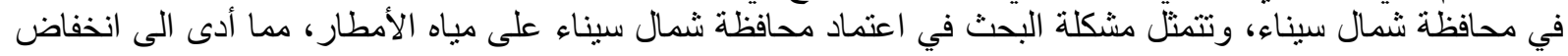

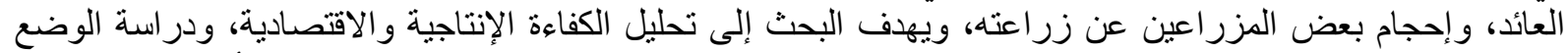

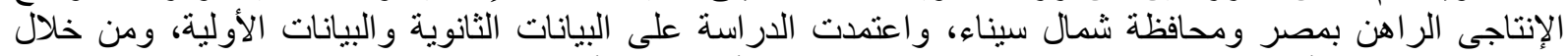

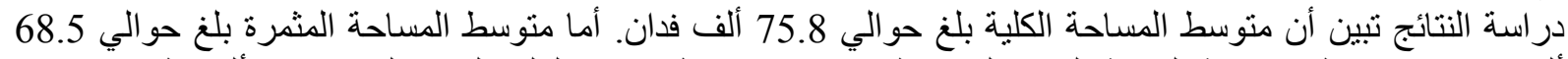

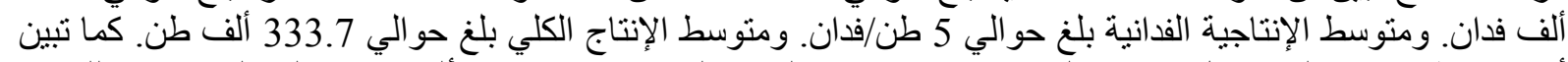

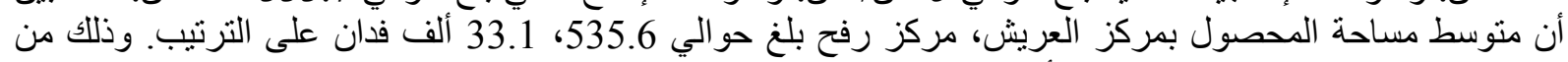

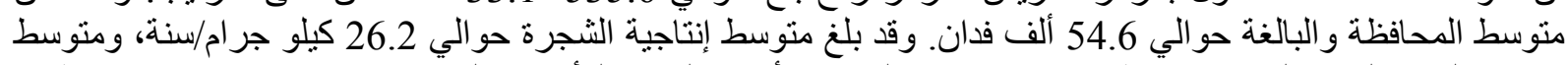

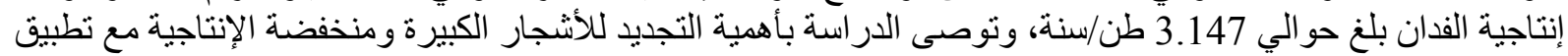
برامج التسميد الكيماوى و والعضوي. الكلمات الإسترشادية: محصول الخوخ، الكفاءة الاقتصادية و الإنتاجية، دو ال الإنتاج و التكاليف، محافظة شمال سيناء.

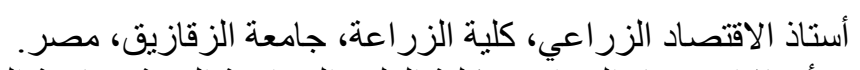

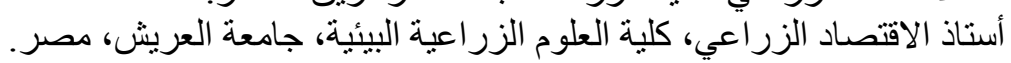

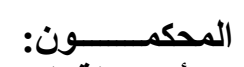

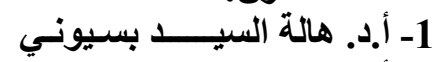
2- أ.د. رياض هاض إسماعيل رضوان بيني 